\title{
Samarium Ion-Promoted Cross-Aldol Reactions and Tandem Aldol/Evans-Tishchenko Reactions
}

\author{
Ling Lu, Hung-Yu Chang, and J im-Min Fang* \\ Department of Chemistry, National Taiwan University, Taipei, Taiwan 106, Republic of China
}

Received August 17, 1998

\begin{abstract}
Cross-al dol reactions of carbonyl compounds were achieved by the catalysis of $\mathrm{Sml}_{2}$ or $\mathrm{Sml}_{3}$, together with molecular sieves, at ambient temperature. 1,3-Dichloroacetone and 1-chloroacetone can be used as acceptor substrates in the cross-aldol reactions with donor substrates such as acetone, cyclopentanone, and cyclohexanone. The cross-aldol reactions with (R)-glyceraldehyde acetonide gave optically pure compounds $\mathbf{2 5}-\mathbf{3 2}$, the stereochemistry of which was in agreement with a chairlike chelate transition state of dipolar mode. Sml ${ }_{2}-$ mol ecular sieves or $\mathrm{Sml}_{3}-$ molecular sieves also functioned as effective $L$ ewis acids to catal yze tandem aldol/Evans-Tishchenko reactions. The aldol/Evans-Tishchenko reactions of methyl ketones with aldehydes occurred at $0{ }^{\circ} \mathrm{C}$ to give $\alpha, \gamma$ anti diol monoesters 53a-59a. When the reactions were conducted at room temperature, a certain degree of transesterification took place. The aldol/Evans-Tishchenko reactions of ethyl or benzyl ketones with aldehydes yielded $\alpha, \beta$-anti- $\alpha, \gamma$-anti diol monoesters 60a-65a. However, the aldol/ Evans-Tishchenko reactions of cyclic ketones with benzaldehyde occurred with a different stereoselectivity to give $\alpha, \beta$-syn- $\alpha, \gamma$-anti diol monoesters 66a-76a. The structures of products were determined by chemical and spectroscopic methods including an X-ray diffraction analysis of 72a derived from the reaction of 4-tert-butylcyclohexanone and benzal dehyde. A reaction mechanism involving dissociation-recombination of aldols followed by intramolecular ster eosel ective hydride shift is proposed, based on some experimental evidence, to explain the dichotomous stereosel ectivity using acyclic or cyclic ketones as the reaction substrates.
\end{abstract}

\section{Introduction}

The use of Ianthanide metal is beneficial to aldol reaction ${ }^{1}$ because lanthanide enolates are less basic than alkali enolates and the aldol products are stabilized by lanthanide ions. ${ }^{2}$ Cross-aldol reactions using samarium enolates have not been extensively studied. ${ }^{3}$ In most reports, $\alpha$-hal oketones are reduced with $\mathrm{Sml}_{2}$ to generate samarium enolates (Reformatsky-type reactions), but the aldol reactions are usually limited to those using aldehydes as the acceptor substrates. $\alpha$-Haloketones, such as 1,3-dichloroacetone (4) and 1-chloroacetone (5), have almost never been used as the aldol acceptors. ${ }^{4}$ This may be due to (i) a lower reactivity of the ketones (compared with aldehydes) due to steric effect, (ii) facile enol ization of $\alpha$-chloroketones due to the electron-withdrawing prop-

(1) (a) Heathcock, C. H. In Comprehensive Organic Synthesis; Trost, B. M., Fleming, I., Eds.; Pergamon Press: Oxford, 1991; Vol. 2, pp 133238. (b) Kim, B. M.; Williams, S. F.; Masamune, S. I bid., 1991; Vol. 2 pp 239-275. For a review, see: (c) Heathcock, C. H. In Asymmetric Synthesis; Morrison, J . D., Ed.; Academic Press: New York, 1984; Vol. 3, pp 111-212. (d) Evans, D. A.; Nelson, J . V.; Taber, T. R. Topics Stereochem. 1982, 13, 1-115.

(2) (a) Molander, G. A. In Comprehensive Organic Synthesis; Trost, B. M., Fleming, I., Eds.; Pergamon Press: Oxford, 1991; Vol. 1, pp 251282. (b) Molander, G. A. Chem. Rev. 1992, 92, 29. (c) I mamoto, T. Lanthanides in Organic Synthesis; Academic Press: London, 1994.

(3) (a) Vougioukas, A. E.; Kagan, H. B. Tetrahedron Lett. 1987, 28 5513. (b) Zhang, Y.; Liu, T.; Lin, R. Synth. Commun. 1988, 18, 2003. (c) Molander, G. A.; Etter, J . B.; Harring, L. S.; Thorel, P.-J . J . Am. Chem. Soc. 1991, 113, 8036. (d) Van de Weghe, P.; Collin, J. Tetrahedron Lett. 1993, 34, 3881. (e) Aoyagi, Y.; Y oshimura, M.; Tsuda, M.; Tsuchibuchi, T.; Kawamata, S.; Tateno, H.; Asano, K.; Nakamura H.; Obokata, M.; Ohta, A.; Kodama, Y.J . Chem. Soc., Perkin Trans. 1 1995, 689. (f) Chuang, T.-H.; Fang, J .-M.; J iaang, W.-T.; Tsai, Y.-M. J. Org. Chem. 1996, 61, 1794.

(4) A report on the addition of 1-(tributylstannyl)acetone with 1,3dichloroacetone: Noltes, J. G.; Creemers, H. M. J. C.; van der Kerk, G. J . M. J . Organomet. Chem. 1968, 11, 21. erty of the $\alpha$-substituent, and (iii) reductive dehalogenation of the $\alpha$-chloroketones by $\mathrm{Sml}_{2}$. However, we have found that cross-aldol reactions using $\alpha$-hal oketones $\mathbf{4}$ and $\mathbf{5}$ as the acceptor substrates were effectively promoted by $\mathrm{Sml}_{2}$, in contrast to the general opinion that $\mathrm{Sml}_{2}$ functions as a oneel ectron reducing agent. 2,3

Under such reaction conditions, we also found that the samarium ion-catalyzed aldol reactions of aldehydes usually proceeded further to give 1,3-diol monoesters via an in situ Tishchenko reaction. ${ }^{5}$ Many natural products such as polyketides and macrolides contain 1,3-diol moieties. ${ }^{6}$ Either anti- or syn-1,3-diols are generally prepared by stereoselective reductions of aldols. ${ }^{7}$ The intramolecular Tishchenko reaction of $\beta$-hydroxy ketones has been carried out stereoselectively by samarium ion catalysis to give anti-1,3-diol monoesters. ${ }^{7 c}$ Ketone enolates (with $\mathrm{Li}^{+}, \mathrm{Zn}^{2+}$, or $\mathrm{Ga}^{3+}$ counterion) are known to undergo tandem aldol-Tishchenko reactions with alde-

(5) Examples of Tishchenko reactions: (a) Yokoo, K.; Mine, N.; Taniguchi, H.; Fujiwara, Y.J . Organomet. Chem. 1985, 279, C19. (b) Collin, J .; Namy, J. L.; Kagan, H. B. Nouv. J . Chem. 1986, 10, 229. (c) Evans, D. A.; Hoveyda, A. H. J . Am. Chem. Soc. 1990, 112, 6447. (d) Onozawa, S.-y.; Sakakura, T.; Tanaka, M.; Shiro, M. Tetrahedron 1996, 52, 4291. (e) Umekawa, Y.; Sakaguchi, S.; Nishiyama, Y.; Ishii, Y.J Org. Chem. 1997, 62, 3409

(6) For reviews: (a) Hoffmann, R. W. Angew. Chem., Int. Ed. Engl. 1987, 26, 9. (b) Oishi, T.; Nakata, T. Synthesis 1990, 635. Examples for using Tishchenko reactions in natural product synthesis: (c) Romo, D.; Meyer, S. D.; J ohnson, D. D.; Schreiber, S. L. J . Am. Chem. Soc. 1993, 115, 7906. (d) Wild, R.; Schmidt, R. R. Tetrahedron: Asymmetry 1994, 5, 2195. (e) Nicolaou, K. C.; Patron, A. P.; Ajito, K.; Richter, P. K.; Khatuya, H.; Bertinato, P.; Miller, R. A.; Tomaszewski, M.J J Chem Eur. J . 1996, 2, 847.

(7) (a) Narasaka, K.; Pai, F.-C. Tetrahedron 1984, 40, 2233. (b) Kiyooka, S.-I.; Kuroda, H.; Shimasaki, Y. Tetrahedron Lett. 1986, 27, 3009. (c) Evans, D. A.; Chapman, K. T.; Carreira, E. M. J . Am. Chem. Soc. 1988, 110, 3560. (d) Szymoniak, J .; Lefranc, H.; Moise, C. J . Org. Chem. 1996, 61, 3926. 
844 J. Org. Chem., Vol. 64, No. 3, 1999

Table 1. Lewis Acid-Promoted Aldol Reactions of Cyclopentanone (7) and 1,3-Dichloroacetone (4)

\begin{tabular}{|c|c|c|c|c|c|c|}
\hline entry no. & Lewis acid (equiv) & additive & methoda $^{a}$ & reaction time/h & products (yield/\%)b & recovered reactants (yield/\%) \\
\hline 1 & $\mathrm{ZnI}_{2}(1.0)$ & & B & 24 & & $7(99)+4(97)$ \\
\hline 2 & $\mathrm{TiCl}_{4}(1.0)$ & $\mathrm{MS}^{\mathrm{c}}$ & B & 0.7 & $16(7)+14(19)$ & $7(78)+4(70)$ \\
\hline 3 & $\mathrm{SmCl}_{3}(1.0)$ & & B & 24 & $14(9)$ & $7(92)+4(82)$ \\
\hline 4 & $\mathrm{SmCl}_{3}(1.0)$ & MS & B & 24 & 14 (11) & $7(90)+4(77)$ \\
\hline 5 & $\mathrm{SmCl}_{3}(0.1)$ & & $\mathrm{B}$ & 48 & $14(6)$ & $7(95)+4(84)$ \\
\hline 6 & $\mathrm{Sml}_{3}(1.0)$ & & B & 0.7 & $16(48)+11(49)$ & $7(25)$ \\
\hline 7 & $\mathrm{Sml}_{3}(1.0)$ & MS & B & 0.7 & $16(50)+11(50)$ & $7(18)$ \\
\hline 8 & $\mathrm{Sml}_{3}(0.1)$ & & B & 0.7 & $16(5)+11(2)$ & $7(81)+4(78)$ \\
\hline 9 & $\mathrm{Sml}_{2}(2.0)$ & MS & B & 0.5 & $16(58)+11(17)$ & $7(10)$ \\
\hline 10 & $\mathrm{Sml}_{2}(1.0)$ & & B & 0.7 & $16(40)+11(36)$ & $7(20)$ \\
\hline 11 & $\mathrm{Sml}_{2}(2.0)$ & MS & A & 0.5 & $16(86)$ & \\
\hline 12 & $\mathrm{Sml}_{2}(1.0)$ & MS & A & 0.5 & $16(63)+11(4)$ & 7 (5) \\
\hline 13 & $\mathrm{Sml}_{2}(0.5)$ & MS & A & 0.5 & $16(48)+11(10)$ & $7(30)$ \\
\hline $14^{\mathrm{d}}$ & $\mathrm{Sml}_{2}(0.5)$ & MS & A & 1.3 & $16(70)+11(7)$ & \\
\hline
\end{tabular}

a The reaction was conducted in THF solution at room temperature $\left(20-25^{\circ} \mathrm{C}\right)$. Cyclopentanone $(3.58 \mathrm{mmol})$ and $1,3-$ dichloroacetone (3.94 mmol, 1.1 equiv) were used. Method A: Cyclopentanone was mixed with Lewis acid to form the metal enolate, and then 1,3dichloroacetone was added. Method B: A mixture of cyclopentanone and 1,3-dichloroacetone was added to the Lewis acid solution. ${ }^{b}$ Compound $\mathbf{1 6}$ is the cross-coupling product of cyclopentanone and 1,3-dichloroacetone; compound $\mathbf{1 4}$ is the self-coupling product of 1,3-dichloroacetone, whereas compound $\mathbf{1 1}$ is a dechlorination derivative of 14. ' $\mathrm{MS}$ represents molecular sieves (4 $\AA$, $200 \mathrm{mg}$ ). ${ }^{\mathrm{d}}$ The aldol reaction was conducted at $0{ }^{\circ} \mathrm{C}$.

hydes to give anti-1,3-diol monoesters. ${ }^{8}$ By the catalysis of $\mathrm{BuTi}(\mathrm{i}-\mathrm{OPr})_{4} \mathrm{Li}$, , e a tandem aldol-Tishchenko reaction between 3-pentanone and benzaldehyde also occurs in a stereoselective manner. We report herein that tandem aldol/Evans-Tishchenko reactions are generally achieved in a highly stereoselective manner by the catalysis of $\mathrm{Sml}_{2}$ or $\mathrm{Sml}_{3}$. However, the stereoselectivity varies depending on whether acyclic or cyclic ketones are utilized as the donor substrates.

\section{Results and Discussion}

In this study, a dark blue THF solution of $\mathrm{Sml}_{2}$ was prepared from Sm and $\mathrm{ICH}_{2} \mathrm{CH}_{2} \mathrm{I}$ (1 equiv) in the presence of molecular sieves. ${ }^{9 a, 10}$ On the other hand, a yellow THF solution of $\mathrm{Sml}_{3}$ was prepared from $\mathrm{Sm}$ and $\mathrm{I}_{2}$ (1.5 equiv) in the presence of molecular sieves. ${ }^{9 b, 10} \mathrm{M}$ olecular sieves (abbreviated MS in this paper) were used in order to facilitate the formation of $\mathrm{Sml}_{2}$ and $\mathrm{Sml}_{3}{ }^{10}$

Aldol Reactions with $\alpha$-Chloroketones. We first examined the cross-aldol reactions of 1,3-dichloroacetone (4) and cyclopentanone (7) (Table 1). Lewis acids $\mathrm{ZnI}_{2}$, $\mathrm{TiCl}_{4}$, and $\mathrm{SmCl}_{3}$ were ineffective for the cross-aldol reactions (entries 1-5). A self-aldol $14(9-19 \%)$ (Figure 1) was formed by the aldol reaction of 1,3-dichloroacetone, and in one case, the desired cross-aldol $\mathbf{1 6}$ was obtained in a small amount (7\%). On the other hand, treatment of ketones 4 and 7 (1:1 mixture) with $\mathrm{Sml}_{2}$ or $\mathrm{Sml}_{3}$ (method B, entries 6-10, Table 1) gave reasonable yields of $\mathbf{1 6}$ (up to $58 \%$ ), accompanied by variable amounts of

(8) Examples of tandem aldol-Tishchenko reactions: (a) Burkhardt, E. R.; Bergman, R. G.; Heathcock, C. H. Organometallics 1990, 9, 30 (b) Curran, D. P.; Wolin, R. L. Synlett 1991, 317. (c) Baramee, A.; Chaichit, N.; Intawee, P.; Thebtaranonth, C.; Thebtaranonth, Y. J. Chem. Soc., Chem. Commun. 1991, 1016. (d) Horiuchi, Y.; Taniguchi, M.; Oshima, K.; Utimoto, K. Tetrahedron Lett. 1995, 36, 5353. (e) Mahrwald, R.; Costisella, G. Synthesis 1996, 1087. (f) Bodnar, P. M.; Shaw, J . T.; Woerpel, K. A. J . Org. Chem. 1997, 62, 5674.

(9) (a) Girard, P.; Namy, J . L.; Kagan, H. B. J . Am. Chem. Soc. 1980 102, 2693. (b) I mamoto, T.; Ono, M. Chem. Lett. 1987, 501.

(10) For a review: (a) Yoon, K. B. Chem. Rev. 1993, 93, 321. Examples of advantageous use of molecular sieves in organic reactions: (b) Hanson, R. M.; Sharpless, K. B. J . Org. Chem. 1986, 51 , 1922. (c) Narasaka, K.; I noue, M.; Yamada, T. Chem. Lett. 1986, 1967. (d) Mikami, K.; Terada, M.; Nakai, T. J. Am. Chem. Soc. 1989, 111 1940. Meerwein-Ponndorf-Verley reduction of aldehydes by using samarium(III) alkoxides and molecular sieves: (e) Ding, Z.-B.; Wu. S.H. Huaxue Xuebao 1997, 55, 351. (f) Ding, Z.-B.; Cheng, K.-J .; Wu. S.-H. Huaxue Xuebao 1997, 55, 1030.<smiles>[R]CC(=O)CC(O)(CCl)CCl</smiles>

$11 \mathrm{R}=\mathrm{H}$

$12 \mathrm{R}=\mathrm{Me}$<smiles>O=C1CCC1C(O)(CCl)CCl</smiles>

$15 n=1$

$16 n=2$

$17 n=3$

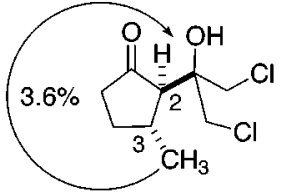

19<smiles>CC(=O)CC(C)(O)CCl</smiles>

21<smiles>CC1OCC2CCCC1(CCl)C2(C)CCl</smiles>

23a (anti)<smiles>[R]CC(=O)C(P)C(O)(CCl)CCl</smiles>

$13 \mathrm{R}=\mathrm{Me}$

$14 \mathrm{R}=\mathrm{Cl}$<smiles>C[C@H]1CC[C@H](C(O)(CCl)CCl)C1=O</smiles>

18a (trans)

$18 \mathrm{~b}($ cis $)$

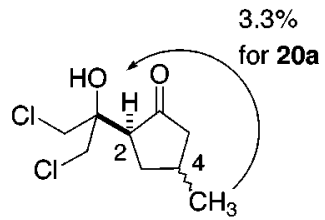

20a (trans)

$20 \mathrm{~b}$ (cis)
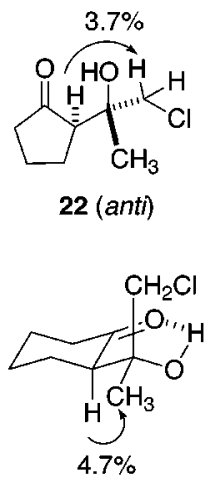

23b (syn)

Figure 1. Samarium ion-promoted cross-aldol reaction products of ketones (Tables 1 and 2). For comparison, syn-aldol 23b was prepared from cyclohexanone lithium enolate and 1-chloroacetone.

aldol $\mathbf{1 1}$ (2-50\%). Compound $\mathbf{1 1}$ was formed by reductive removal of the $\alpha$-chlorine atoms from $\mathbf{1 4}$ (see below). No products (secondary alcohols or vicinal diols) formed by reduction or pinacol coupling of ketone $\mathbf{4}$ or $\mathbf{7}$ were observed. Reduction and pinacol coupling of aliphatic 


\section{Scheme 1}

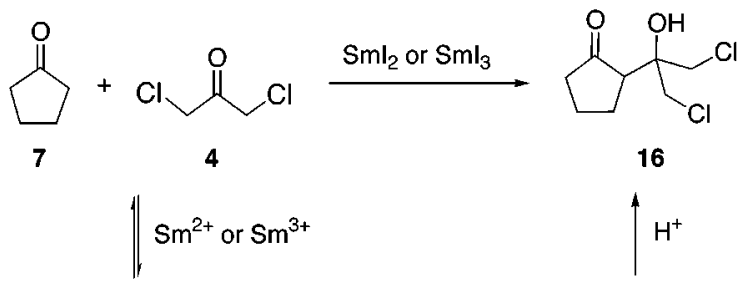

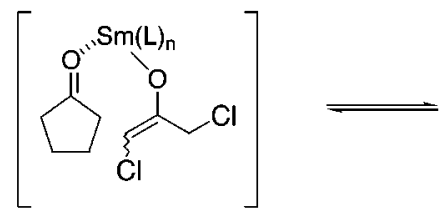

A

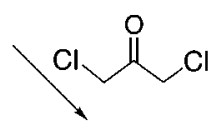

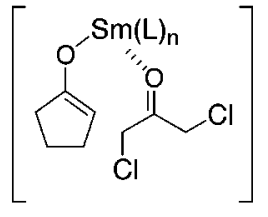

B

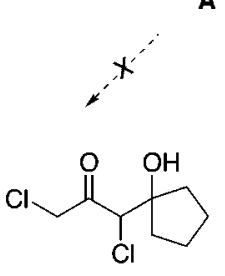

C (not observed)

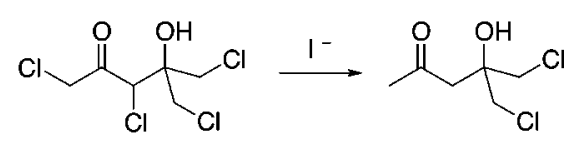

11 ketones with $\mathrm{Sml}_{2}$ usually require the presence of a proton source (e.g., t-BuOH) or a polar solvent (e.g., HMPA); otherwise, these reactions are sluggish. ${ }^{11}$ In THF solution (this study), enolization of ketones and the subsequent aldol reactions appeared to be faster than reduction and pinacol coupling.

According to this procedure (method $\mathrm{B}$ ), $\mathrm{Sml}_{2}$ and molecular sieves functioned as a combined Lewis acid catalyst. Compound $\mathbf{1 6}$ was conceivably derived by addition of cyclopentanone enolate to 1,3-dichloroacetone via a transition state B (Scheme 1). The alternative crossaldol reaction, giving $\mathbf{C}$ by addition of 1,3-dichloroacetone enolates to cyclopentanone, did not occur. Since the acidity of $\alpha$-proton in 1,3-dichloroacetone is higher than in cyclopentanone, we presume that the samarium enolates of 1,3-dichloroacetone (E- or Z-forms) were primarily generated (transition state $\mathbf{A})$. The samarium enolates would be less basic and less reactive than the corresponding lithium enolates. Thus, the 1,3-dichloroacetone enolates A could not add to the less reactive carbonyl center of cyclopentanone. I nstead, the samarium enolates might undergo a transenolization by abstraction of an $\alpha$-proton of cyclopentanone (from A to B). The cyclopentanone enolate generated as such reacted readily with 1,3-dichloroacetone to give the cross-aldol 16. On the other hand, 1,3-dichloroacetone enolates could al so react with another molecule of 1,3-dichloroacetone to afford a self-al dol 14. Reductive removal of $\alpha$-chlorine atoms from $\mathbf{1 4}$ would afford $\mathbf{1 1}$. We consider that the $\mathrm{I}^{-}$ion, ${ }^{12}$ not $\mathrm{Sml}_{2}$, is responsible for the dechlorination, as compound $\mathbf{1 1}$ was al so obtained from the reaction with $\mathrm{Sml}_{3}$ (entries 6-8, Table 1).

The yield of aldol $\mathbf{1 6}$ was increased by treatment of a preformed cyclopentanone enolate with 1,3-dichloro-

(11) (a) Namy, J . L.; Souppe, J .; Kagan, H. B. Tetrahedron Lett. 1983, 24, 765. (b) Hasegawa, E.; Curran, D. P. J . Org. Chem. 1993 58, 5008.

(12) Use of $\mathrm{Cel}_{3}$ or $\mathrm{Nal}$ for dehalogenation of $\alpha$-chloroketones: (a) Gemal, A. L.; Luche, J . L. Tetrahedron Lett. 1980, 21, 3195. (b) Fukuzawa, S.-i.; Tsuruta, T.; Fujinami, T.; Sakai, S. J . Chem. Soc., Perkin Trans. 1 1987, 1473. acetone at room temperature (method A). Accordingly, the reaction using 2.0 equiv of $\mathrm{Sml}_{2}$ (entry 11 ) in the presence of molecular sieves afforded an $86 \%$ yield of $\mathbf{1 6}$. The reaction using a substoichiometric amount of $\mathrm{Sml}_{2}$ (entries 13 and 14) gave lower yields of $\mathbf{1 6}$ together with small amounts of $\mathbf{1 1}$ (Figure 1 ).

The Sml 2 -MS-mediated cross-aldol reactions of 1,3dichloroacetone with other cyclic or acyclic ketones were successfully carried out (Table 2 ). These reactions using preformed enolates (method A) were complete in 40 min at ambient temperature. The reaction of 2-butanone occurred exclusively at C-1 (the methyl site), giving aldol 12. The reaction of 2-methylcyclopentanone al so occurred at the less substituted $\alpha$-carbon, giving the product $\mathbf{1 8}$ $(80 \%)$ as a mixture of two isomers (4:1). The major isomer might have a trans configuration by analogy with the result of the reaction of 3-methylcyclopentanone. The reaction of 3-methylcyclopentanone occurred at both $\alpha$ and $\alpha^{\prime}$-carbons, giving aldols 19, 20a, and $\mathbf{2 0 b}$ in a ratio of 27:63:10, as shown by the ${ }^{1} \mathrm{H}$ NMR spectrum (300 $\mathrm{MHz}$ ). Although 19, 20a, and 20b were not completely separated, the detailed NMR spectral analyses $(500 \mathrm{MHz})$ indicated that 19 and $20 \mathrm{a}$ had trans configurations. Their proton resonances were assigned by assistance of the $\mathrm{H}-\mathrm{H}$ COSY and TOCSY spectra. Thus, irradiation of the methyl group (at $\delta 1.22$ ) of compound 19 caused a 3.6\% NOE of $\mathrm{H}-2$ (at $\delta 2.17, \mathrm{~d}, \mathrm{~J}=9.5 \mathrm{~Hz}$ ). When the methyl group (at $\delta 1.02$ ) of compound 20a was irradiated, a 3.3\% enhancement of $\mathrm{H}-2$ (at $\delta 2.63, \mathrm{t}, \mathrm{J}=7.6 \mathrm{~Hz}$ ) was also observed.

An unsymmetric ketone, 1-chloroacetone (5), was also utilized as an acceptor substrate for the $\mathrm{Sml}_{2}-\mathrm{MS}$ mediated cross-aldol reactions. The reactions using cyclopentanone or cyclohexanone as donor substrates afforded anti-aldols 22 and 23a. To determine the configuration, we also prepared a mixture of $\mathbf{2 3}$ a and its syn isomer $\mathbf{2 3 \mathbf { b }}(\mathbf{1 : 1 )}$ by addition of 1-chloroacetone to the lithium enolate of cyclohexanone. The NOE experiments clearly indicated the configurations of $\mathbf{2 3} \mathbf{a}$ and $\mathbf{2 3 \mathbf { b }}$. I rradiation of the axially oriented $\mathrm{H}-2$ (at $\delta 2.82$, dd, J = $12.4,5.5 \mathrm{~Hz}$ ) of $\mathbf{2 3 a}$ caused a $3.1 \%$ enhancement of the $\mathrm{CH}_{2} \mathrm{Cl}$ signal (at $\delta 3.40$ and 3.62 as an $\mathrm{AB}$ quartet), whereas irradiation of the axially oriented $\mathrm{H}-2$ (at $\delta 2.66$, $\mathrm{dd}, \mathrm{J}=12.4,5.4 \mathrm{~Hz}$ ) of $\mathbf{2 3 b}$ caused a $4.7 \%$ enhancement of the methyl group (at $\delta 1.28$ ). The anti configuration of aldol $\mathbf{2 2}$ was similarly determined; that is, irradiation of $\mathrm{H}-2$ (at $\delta 2.58$ ) caused a $3.7 \% \mathrm{NOE}$ of the $\mathrm{CH}_{2} \mathrm{Cl}$ group.

Aldol Reactions with (R)-Glyceraldehyde Acetonide. The samarium ion-catalyzed aldol reactions using (R)-glyceraldehyde acetonide (24) as the acceptor substrate led to optically pure products 25-32 (Table 3, Figure 2). The cross-aldol reactions were carried out by either method A with preformed enol ate or by method B with concurrent addition of a mixture of substrates. For example, compound $\mathbf{2 5}$ with the (4S,5R)-configuration, 13 a $[\alpha]^{26}-27\left(\mathrm{CHCl}_{3}, \mathrm{C}=1.0\right)$, was obtained in $70 \%$ yield simply by treatment of a mixture of acetone and $\mathbf{2 4}$ (1:1) in the THF solution of $\mathrm{Sml}_{2}-\mathrm{MS}$ (method $B$ ). The reaction of 1-chloroacetone and $\mathbf{2 4}$ (method A, entry 5 of Table 3) also afforded 25 (74\%) after in situ removal of the $\alpha$-chlorine atom. Our present method is superior to

(13) For compound 25: (a) Cubero I I · Lopez-E spinosa, M. T. P Gonzalez, D. G. Carbohydr. Res. 1986, 148, 209. For compound 26 : (b) Aparicio, F. J . L.; Cubero, I. I.; Olea, M. D. P. Carbohydr. Res. 1982, 103, 158. (c) Cubero, I. I.; Lopez-Espinosa, M. T. P. Carbohydr. Res. 1986, 154, 71. 
Table 2. Aldol Reactions Promoted by $\mathrm{Sml}_{2}$ (2.0 equiv) and Molecular Sieves (THF, $\left.20-25^{\circ} \mathrm{C}\right)^{\mathrm{a}}$

\begin{tabular}{|c|c|c|c|c|}
\hline entry no. & donor & acceptor & reaction time/min & products (yield/\%) \\
\hline 1 & acetone (1) & 1,3-dichloroacetone (4) & 15 & $11(90)$ \\
\hline 2 & 2-butanone (2) & 4 & 40 & $12(75)$ \\
\hline 3 & 3-pentanone (3) & 4 & 40 & $13(81)$ \\
\hline 4 & cyclobutanone (6) & 4 & 40 & $15(53)$ \\
\hline 5 & cyclopentanone $(\mathbf{7})$ & 4 & 30 & $16(86)$ \\
\hline 6 & cyclohexanone (8) & 4 & 30 & $17(63)$ \\
\hline 7 & 2-methylcycl opentanone (9) & 4 & 40 & $18 \mathbf{a} / \mathbf{1 8 b}(80)^{b}$ \\
\hline 8 & 3-methylcyclopentanone (10) & 4 & 40 & $19 a / 20 a / 20 b(68)$ \\
\hline 9 & 1 . & 1-chloroacetone (5) & 15 & 21 (87) \\
\hline 10 & 5 & 5 & 20 & $21(86)$ \\
\hline 11 & 7 & 5 & 20 & $22(75)$ \\
\hline 12 & 8 & 5 & 30 & $23 a(63)$ \\
\hline
\end{tabular}

a The reaction was conducted by addition of the acceptor substrate (1.1 equiv) to the preformed samarium enolate of the donor substrate (1.0 equiv) according to method $A$ described in Table 1 . $b$ The ratio of trans- and cis-isomers $\mathbf{1 8 a} / \mathbf{1 8 b}=4: 1$. ${ }^{c}$ The ratio of $\mathbf{1 9 a} / \mathbf{2 0 a} / \mathbf{2 0 b}=$ 27:63:10.

Table 3. Aldol Reactions of Ketones (1.1 equiv) and (R)-Glyceraldehyde Acetonide (24) (1.0 equiv) Promoted by Sml 2 (2.0 equiv) and Molecular Sieves (THF, 20-25 $\left.{ }^{\circ} \mathrm{C}\right)^{\mathrm{a}}$

\begin{tabular}{|c|c|c|c|c|c|}
\hline entry no. & ketone & additive & method & reaction time/min & products (yield/\%) \\
\hline 1 & acetone $(\mathbf{1})$ & $\mathrm{t}-\mathrm{BuOH}$ & B & 15 & $25(70)$ \\
\hline 2 & 2-butanone (2) & & A & 40 & $26(77)$ \\
\hline 3 & 3-pentanone (3) & & A & 40 & $27(85)$ \\
\hline 4 & 1,3-dichloroacetone $(\mathbf{4})^{\mathrm{b}}$ & & A & 20 & $28(61)$ \\
\hline 5 & 1-chloroacetone (5) & & A & 20 & $25(74)$ \\
\hline 6 & cyclopentanone (7) & & A & 30 & $29(47)$ \\
\hline 7 & 7 & & B & 30 & $29(45)$ \\
\hline 8 & 7 & $\mathrm{t}-\mathrm{BuOH}$ & B & 20 & $29(78)$ \\
\hline gc & 7 & & A & 300 & $29(70)$ \\
\hline 10 & $7^{d}$ & $\mathrm{t}-\mathrm{BuOH}$ & B & 30 & $29(68)^{d}$ \\
\hline 11 & cyclohexanone (8) & & A & 30 & $30(50)$ \\
\hline 12 & 8 & $\mathrm{t}-\mathrm{BuOH}$ & B & 30 & $30(62)$ \\
\hline 13 & 2-methylcyclopentanone (9) & & A & 40 & $31(60)^{e}+32(16)$ \\
\hline
\end{tabular}

a The reaction was conducted according to methods A or B described in Table 1, whereas t-BuOH (2.0 equiv) was added in appropriate entries. b 1,3-Dichloroacetone (2 equiv) was used. c Substoichiometric amount of $\mathrm{Sml}_{2}$ (0.5 equiv) was used. d Cyclopentanone (2 equiv) was used. The self-aldol product of cyclopentanone was also isolated in 18\% yield. e It contained two C-5 epimers 31a/31b $=4: 1$.<smiles>CC(=O)C[C@H](O)[C@H]1COC(C)(C)O1</smiles>

25<smiles>CC1(C)OC[C@@H]([C@H](O)CC(=O)CC(O)(CCl)CCl)O1</smiles>

28

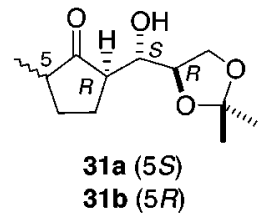

Figure 2. Cross-aldol reaction products of ketones and ( $R$ )glyceraldehyde acetonide (Table 3).

the previous nonselective preparation, ${ }^{13 a}$ which requires a multistep sequence to produce a mixture of $\mathbf{2 5}$ and its $(4 \mathrm{R}, 5 \mathrm{R})$-isomer.

The cross-aldol reaction of 2-butanone occurred at the more substituted $\alpha^{\prime}$-site to give 26 (77\%) with the (3R,4S,5R)-configuration. Compound 26 exhibited an optical rotation, $[\alpha]^{26}{ }_{\mathrm{D}}+24\left(\mathrm{CHCl}_{3}, \mathrm{C}=0.35\right)$, cl ose to the reported value. ${ }^{13}$ The C-3 methyl group of $\mathbf{2 6}$ appeared at $\delta_{\mathrm{C}} 14.1 \mathrm{ppm}$, a typical position for 4,5-anti aldols. ${ }^{14}$
The corresponding signals of 4,5-syn aldols usually appeared at higher fields $\left(\delta_{\mathrm{C}}<10 \mathrm{ppm}\right){ }^{14}$ The regioselectivity was different from the reaction with 1,3dichloroacetone, which occurred at the methyl site of 2-butanone to give $\mathbf{1 2}$. The addition of a rather bulky ketone (1,3-dichloroacetone) at the methylene site (C-3) of 2-butanone was presumably disfavored. A different process of transenolization (Scheme 1) might also change the regiochemistry.

The cross-aldol reaction between 3-pentanone and 24 yielded an aldol $\mathbf{2 7}$ with the (4R,5S,6R)-configuration. The resonance of the C-4 methyl group of 27, appearing at $\delta_{\mathrm{C}} 14.3 \mathrm{ppm}$, is diagnostic for the stereochemical assignment. ${ }^{14}$ When 1,3-dichloroacetone (2 equiv) was treated with $\mathrm{Sml}_{2}$ (2.1 equiv) in THF followed by addition of (R)-glyceral dehyde acetonide (1 equiv), an uncommon double cross-aldol product 28 (61\%) was obtained after in situ removal of four $\alpha$-chlorine atoms.

The Sml 2 -promoted cross-aldol reactions of cyclopentanone and cyclohexanone with (R)-glyceraldehyde acetonide were carried out by either method $A$ or method $\mathrm{B}$ (with or without $\mathrm{t}-\mathrm{BuOH}$ ) to give the enantiomerically pure aldols 29 and $\mathbf{3 0}$. Their structures were inferred from mechanistic considerations (see Scheme 4). The cross-aldol reaction of 2-methylcyclopentanone occurred at both $\alpha$ - and $\alpha^{\prime}$-carbons, giving 31 (60\%) and 32 (16\%). Though the addition of (R)-glyceraldehyde acetonide at the more substituted $\alpha^{\prime}$-carbon was a minor pathway, this

(14) Heathcock, C. H.; Pirrung, M. C.; Sohn, J. E. J . Org. Chem. 1979, 44, 4294. 
Scheme 2<smiles>CCCCC(=O)[CH+]CC(=O)C1COC(C)(C)C1(C)C</smiles>

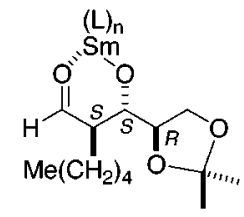

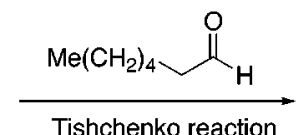

34

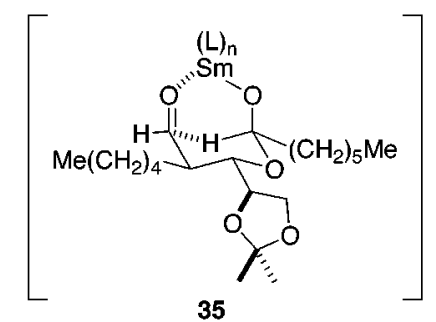

$\mathrm{H}^{+}$<smiles>CC(=O)O[C@H](C(CO)CO)[C@@H]1OC(C)(C)O[C@H]1C</smiles>

Scheme 3

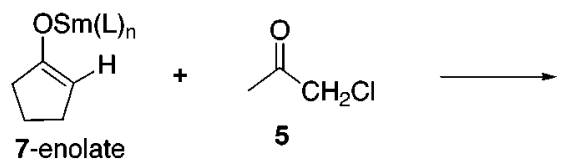<smiles>CC(C)(CCl)[C@H]1CCCC1C(=O)O</smiles>

reaction showed the feasibility for construction of a new quaternary carbon center.

Aldol/Evans-Tishchenko Reaction of Heptanal and (R)-Glyceraldehyde Acetonide. The $\mathrm{Sml}_{2}$-catalyzed aldol reaction of heptanal (2 equiv) with (R)glyceraldehyde acetonide (1 equiv) proceeded with a subsequent Tishchenko reaction to give a diol monoester 36 , which was considered to have the $(2 \mathrm{R}, 3 \mathrm{~S}, 4 \mathrm{~S})$-configuration (Scheme 2). The 3,4-anti relationship in the aldol intermediate $\mathbf{3 4}$ was established by a mechanism similar to that operating in the reaction of 3-pentanone with (R)glyceraldehyde acetonide (see Scheme 4). Under such samarium ion-catalyzed conditions, an acetal intermediate $\mathbf{3 5}$ formed and underwent an intramolecular hydride shift to give the observed product 36.

Aldol/Evans-Tishchenko Reactions of Acyclic Ketones. Both $\mathrm{Sml}_{2}$ and $\mathrm{Sml}_{3}$ were effective catalysts for tandem al dol/E vans-Tishchenko reactions (Tables 4

\section{Scheme 4}

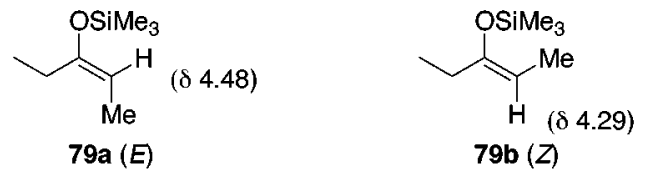<smiles>CCC(C)=C(C)OC</smiles>

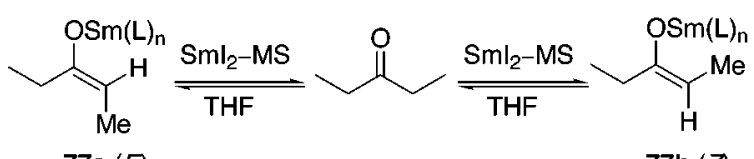

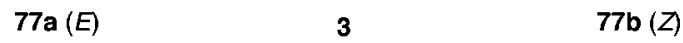<smiles>CC1(C)OCC(C=O)O1</smiles>

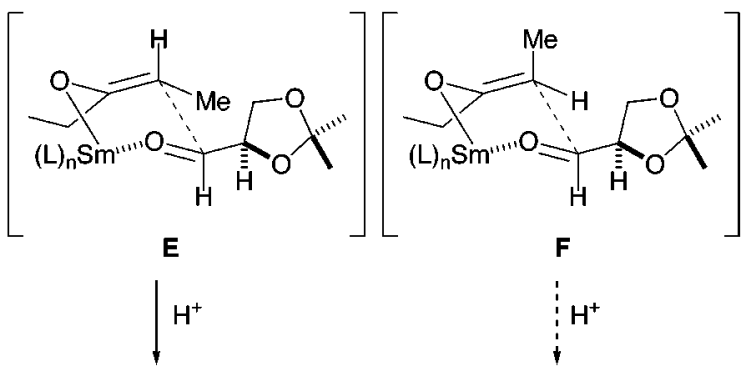<smiles>CCOC(=O)C(C)C(O)C(O)C(=O)CC</smiles><smiles>CCC(=O)[C@H](O)[C@H](O)[C@H]1COC(C)(C)O1</smiles>

$80(4,5-s y n)$

(not observed)

and 5). For example, acetophenone was treated with $\mathrm{Sml}_{2}$ (30 mol \%) in the presence of molecular sieves at $0{ }^{\circ} \mathrm{C}$, followed by addition of benzal dehyde ( 2.5 equiv), to afford a diol monoester 53 a (Figure 3 ) in $84 \%$ yield. Saponification of 53a led to a known compound 53 c having the $\alpha, \gamma$ anti configuration. ${ }^{15 a, b}$ Greeks $\alpha-\gamma$ are used in this paper to avoid confusion with carbon numbering in products. The carbon bearing a carboxy group of the aldol/EvansTishchenko product (without transesterification) is designated as the $\alpha$-carbon (see structures 53a, 61a, and 69a). The carbon chains of products are depicted as extended zigzag forms; the relative configuration of the substituents are designated as syn when they are on the same face and as anti when they are on opposite faces. The tandem aldol/Evans-Tishchenko reaction of acetophenone with isobutyraldehyde proceeded similarly to give the known $\alpha, \gamma$-anti diol $\mathbf{5 5 c}^{\text {,b }}$ after a subsequent hydrolysis. The characteristic C -1 and C-3 resonances of 55c appeared at higher fields ( $\delta 73.86$ and 71.83), due to the $\gamma$-gauche effect, than the corresponding carbons in the $\alpha, \gamma$-syn isomer (at $\delta 76.97$ and 74.89). ${ }^{7 b}$ The

(15) For compound 53c: (a) Yamamoto, K.; Ando, H.; Chikamatsu H. J. Chem. Soc., Chem. Commun. 1987, 334. (b) Corey, E. J .; Chen Z. Tetrahedron Lett. 1994, 35, 8731. For compound 55c: see ref 7b. For compounds 67c and 68c: (c) Thompson, S. H. J .; Mahon, M. F.; Molloy, K. C.; Hadley, M. S.; Gallagher, T.J . Chem. Soc., Perkin Trans. 1 1995, 379. 
Table 4. Tandem Aldol/E vans-Tishchenko Reactions Promoted by $\mathrm{Sml}_{2}(0.3$ equiv) in the Presence of Molecular Sieves $\left(\mathrm{THF}, \mathrm{O}^{\circ} \mathrm{C}\right)^{\mathrm{a}}$

\begin{tabular}{|c|c|c|c|c|}
\hline entry no. & donora & acceptora $^{a}$ & reaction time/h & products (yield/\%) \\
\hline $1^{\mathrm{b}}$ & heptanal (33) & (R)-glyceraldehyde acetonide (24) & 0.5 & $36(85)$ \\
\hline 2 & acetophenone (40) & benzal dehyde (37) & 2 & $53 a(84)$ \\
\hline $3^{c}$ & 40 & propional dehyde (38) & 2 & $\mathbf{5 4 a / 5 4 b}(68)^{d}$ \\
\hline 4 & 40 & isobutyraldehyde (39) & 2 & $55 a(72)$ \\
\hline 5 & 3,3-dimethyl-2-butanone (41) & 37 & 4 & $56 a(80)$ \\
\hline 6 & 41 & 39 & 4 & $57 a(80)$ \\
\hline 7 & cyclohexyl methyl ketone (42) & 37 & 3 & $58 a(80)$ \\
\hline 8 & 2-butanone (2) & 37 & 2 & $59 a / 59 b / 60 a / 60 b(83)^{e}$ \\
\hline 9 & 3-pentanone (3) & 37 & 1 & $61 \mathbf{a}(77)+\mathbf{6 1 b}(9)$ \\
\hline $10^{c}$ & 3 & 37 & 2 & $61 \mathbf{a}(12)+\mathbf{6 1 b}(76)$ \\
\hline 11 & 3 & 38 & 0.5 & $62 a(79)$ \\
\hline $12^{c}$ & 3 & 39 & 2 & $63 a(50)+63 b(28)$ \\
\hline 13 & propiophenone (43) & 37 & 4 & $64 a(90)$ \\
\hline 14 & deoxybenzoin (44) & 37 & 4 & $65 a(88)$ \\
\hline 15 & cyclobutanone (6) & 37 & 1 & $66 \mathbf{a}(80)$ \\
\hline 16 & cyclopentanone $(\mathbf{7})$ & 37 & 2 & $67 a(85)$ \\
\hline 17 & cyclohexanone (8) & 37 & 3 & $68 \mathbf{a}(88)$ \\
\hline 18 & 1,4-cyclohexanedione (45) & 37 & 4 & $69 a(80)$ \\
\hline 19 & 1,4-cyclohexanedione monoethylene acetal (46) & 37 & 5 & $70 \mathbf{a}(93)$ \\
\hline 20 & 4-methylcyclohexanone (47) & 37 & 3 & 71 a (95) \\
\hline 21 & 4-tert-butylcycl ohexanone (48) & 37 & 4 & $72 a(85)$ \\
\hline 22 & tetrahydro-4H-pyran-4-one (49) & 37 & 4 & $73 \mathbf{a}(84)$ \\
\hline 23 & 2-cyclohexenone (50) & 37 & 5 & $74 a(92)$ \\
\hline 24 & $\alpha$-tetralone (51) & 37 & 2 & $75 a(77)$ \\
\hline 25 & trans-1-decalone (52) & 37 & 6 & $76 a(81)$ \\
\hline
\end{tabular}

a The dark blue $\mathrm{Sml}_{2}(0.1 \mathrm{M})-\mathrm{THF}(3 \mathrm{~mL})$ suspension was prepared by treatment of $\mathrm{Sm}(0.3 \mathrm{mmol})$ with diiodoethane $(0.3 \mathrm{mmol})$ in the presence of molecular sieves $(4 \AA, 100 \mathrm{mg})$. The enolate of donor substrate $(1 \mathrm{mmol})$ was formed at $0{ }^{\circ} \mathrm{C}$, after which the acceptor substrate $(2.5 \mathrm{mmol})$ was added. ${ }^{\mathrm{b}}$ Heptanal $(2.0 \mathrm{mmol})$, (R)-glyceral dehyde $(1.0 \mathrm{mmol})$, and $\mathrm{Sml} 2$ ( 2.1 mmol) were used. ${ }^{\mathrm{c}}$ The reaction

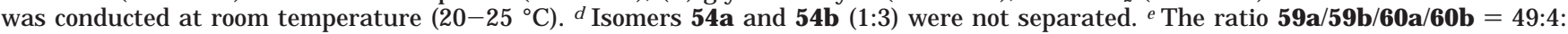
40:7.

Table 5. Tandem Aldol/E vans-Tishchenko Reactions Promoted by $\mathrm{Sml}_{3}(0.3$ equiv) in the Presence of Molecular Sieves (THF, $0^{\circ} \mathrm{C}$ ) Using Benzaldehyde (2.5 equiv) as the Acceptora

\begin{tabular}{|c|c|c|c|}
\hline entry no. & donor (1.0 equiv) & reaction time/h & products (yield/\%) \\
\hline 1 & acetophenone & 6 & 53a (80) \\
\hline 2 & 3,3-dimethyl-2-butanone & 14 & $56 a(78)$ \\
\hline 3 & cyclohexyl methyl ketone & 8 & $58 a(84)$ \\
\hline $4^{b}$ & 2-butanone & 14 & $59 b(41)+60 b(41)$ \\
\hline 5 & 3-pentanone & 14 & $61 \mathbf{a}(85)$ \\
\hline 6 & propiophenone & 10 & $64 a(90)$ \\
\hline 7 & deoxybenzoin & 10 & 65a (87) \\
\hline 8 & cyclobutanone & 4 & $66 \mathbf{a}(81)$ \\
\hline 9 & cyclopentanone & 6 & $67 a(87)$ \\
\hline 10 & cyclohexanone & 8 & 68a (89) \\
\hline 11 & 1,4-cyclohexanedione & 10 & 69a (90) \\
\hline 12 & 1,4-cyclohexanedione monoethylene acetal & 10 & $70 \mathbf{a}(89)$ \\
\hline 13 & 4-methylcyclohexanone & 8 & $71 \mathbf{a}(91)$ \\
\hline 14 & 4-tert-butylcyclohexanone & 12 & $72 a(84)$ \\
\hline 15 & tetrahydro-4H-pyran-4-one & 13 & 73a (81) \\
\hline 16 & 2-cyclohexenone & 14 & $74 a(89)$ \\
\hline 17 & $\alpha$-tetralone & 6 & 75a (77) \\
\hline 18 & trans-1-decalone & 12 & $76 \mathbf{a}(79)$ \\
\hline
\end{tabular}

a The yellow $\mathrm{Sml}_{3}(0.06 \mathrm{M})$-THF $(5 \mathrm{~mL})$ suspension was prepared by treatment of $\mathrm{Sm}(0.3 \mathrm{mmol})$ with $\mathrm{I}_{2}(0.45 \mathrm{mmol})$ in the presence of molecular sieves $(4 \AA, 100 \mathrm{mg})$. The enolate of donor substrate $(1 \mathrm{mmol})$ was formed at $0{ }^{\circ} \mathrm{C}$, after which the acceptor substrate $(2.5$ $\mathrm{mmol}$ ) was added. $\mathrm{b}$ The reaction was conducted at room temperature $\left(20-25^{\circ} \mathrm{C}\right)$.

samarium ion-catalyzed reaction of 3,3-dimethyl-2butanone (41) with benzaldehyde gave a diol monoester 56a (ca. $80 \%$ ) at $0{ }^{\circ} \mathrm{C}$, whereas the nickel-bound enolate of $\mathbf{4 1}$ has been shown to react with benzal dehyde to give a mixture of 56a and its transesterification isomer. ${ }^{8 a}$

The tandem aldol/Evans-Tishchenko reaction of cycl ohexyl methyl ketone with benzal dehyde occurred in a regio- and stereoselective fashion to give the diol monoester 58a with anti configuration. However, the tandem aldol/Evans-Tishchenko reaction of 2-butanone occurred at both $\alpha$ - and $\alpha^{\prime}$-carbons, giving 59a, b and $60 \mathrm{a}, \mathrm{b}$ in nearly equal amounts. Compounds $59 \mathrm{~b}$ and $60 \mathrm{~b}$ were the transesterification products of $59 a$ and 60 a. The structures were deduced from their ${ }^{1} \mathrm{H}$ NMR spectra, in which the signals of methyl groups and the chemical shifts of $\mathrm{H}-1$ and $\mathrm{H}-3$ were most diagnostic. The methyl groups of $60 \mathrm{a}$ and $60 \mathrm{~b}$ exhibited as doublets, whereas the methyl groups of $\mathbf{5 9 a}$ and $\mathbf{5 9 b}$ displayed as triplets. The $\mathrm{H}-\mathbf{1}$ signals of the transesterification products $\mathbf{5 9 b}$ and $60 \mathrm{~b}$ showed at lower fields ( $\delta 4.67$ and 4.29 ) than the $\mathrm{H}-3$ signals of 59a and 60a (at $\delta 3.68$ and 4.17). On the other hand, the $\mathrm{H}-3$ signals of $59 \mathrm{~b}$ and $\mathbf{6 0 b}$ appeared at higher fields ( $\delta 5.38$ and 5.82) than the $\mathrm{H}-1$ signals of $59 \mathbf{a}$ and $60 \mathbf{a}$ (at $\delta 6.37$ and 5.98). A mixture of 59a, 59b, 60a, and 60b (49:4:40:7) was subjected to hydrolysis $(\mathrm{NaOH}, \mathrm{MeOH})$ to give the (1S*,3R*)-diol 59c and $\left(1 S^{*}, 2 S^{*}, 3 R^{*}\right)$-diol $60 \mathrm{c}$ in a ratio of 53:47, in agreement with the stereochemical assignment. 
<smiles>OC(C[C@@H](O)c1ccccc1)c1ccccc1</smiles>

53a $\mathrm{R}=\mathrm{PhCO}$

$53 \mathrm{C} R=\mathrm{H}$<smiles>CC(C)[C@@H](O)CC(O)c1ccccc1</smiles>

$55 \mathrm{a} \mathrm{R}=\mathrm{Me}_{2} \mathrm{CHCO}$

55c $R=H$<smiles>O=C(OC(CC(O)C1CCCCC1)c1ccccc1)c1ccccc1</smiles>

$58 a$<smiles>CC(O)C(C)[C@@H](O[Tl])c1ccccc1</smiles>

60a $\mathrm{R}^{1}=\mathrm{PhCO}, \mathrm{R}^{2}=\mathrm{H}$

60b $R^{1}=H, R^{2}=P h C O$

60c $R^{1}=R^{2}=H$<smiles>CCC(O)C(C)[C@H](O)CC</smiles>

62a $\mathrm{R}=\mathrm{EtCO}$

$62 c \mathrm{R}=\mathrm{H}$<smiles>CCC(O)CC(O[Ga])c1ccccc1</smiles>

54a $\mathrm{R}^{1}=\mathrm{EtCO}, \mathrm{R}^{2}=\mathrm{H}$

54b $R^{1}=H, R^{2}=E t C O$<smiles>[R]C(=O)O[C@@H]([R])CC(O)C(C)(C)C</smiles>

56a $\mathrm{R}=\mathrm{Ph}$

57a $\mathrm{R}=i-\mathrm{Pr}$<smiles>[R7]OC(CC)CC(O)c1ccccc1</smiles>

59a $\mathrm{R}^{1}=\mathrm{PhCO}, \mathrm{R}^{2}=\mathrm{H}$ $59 b R^{1}=H, R^{2}=P h C O$ 59c $R^{1}=R^{2}=H$<smiles>CCC(O)C(C)[C@@H](O[Ga])[C@H](O)c1ccccc1</smiles>

61a $R^{1}=\mathrm{PhCO}, \mathrm{R}^{2}=\mathrm{H}$ 61b $R^{1}=H, R^{2}=P h C O$ 61c $R^{1}=R^{2}=H$<smiles>CCOC(CC)C(C)[C@@H](O[Tl])C(C)C</smiles>

63a $\mathbf{R}^{1}=j-\mathrm{PrCO}, \mathbf{R}^{2}=\mathrm{H}$ 63b $\mathrm{R}^{1}=\mathrm{H}, \mathrm{R}^{2}=i-\mathrm{PrCO}$<smiles>O=C(OC(c1ccccc1)c1ccccc1)C(O)C(O)c1ccccc1</smiles>

64a $\mathrm{R}=\mathrm{Me}$

65a $\mathrm{R}=\mathrm{Ph}$

Figure 3. $\alpha, \gamma$-Anti and $\alpha, \beta$-anti- $\alpha, \gamma$-anti products from the aldol/Evans-Tishchenko reactions of acylic ketones.

The samarium ion-catalyzed reaction of 3-pentanone with benzaldehyde proceeded in a highly stereoselective manner at $0{ }^{\circ} \mathrm{C}$ to give the diol monoester 61a (85\%). The reaction at room temperature yielded a mixture of 61a and its transesterification product 61b (14:86). Transesterification tended to occur at room temperature for a prolonged period (compared entries 9 and 10 of Table 4). A similar reaction using a titanium complex $\mathrm{BuTi}(\mathrm{Oi}-\mathrm{Pr})_{4} \mathrm{Li}$ as the catalyst has been reported. ${ }^{8 \mathrm{e}}$ Hydrolysis of either 61a or 61b gave a diol 61c, which had the $\alpha, \beta$-anti- $\alpha, \gamma$-anti configuration. The characteristic carbon resonances of 61c occurred at $\delta 10.6$ (C-5), 11.4 (Me-2), 73.9 (C-3), and 76.6 (C-1), compatible with chemical shifts of known analogues. ${ }^{8 a}$ In our study, all tandem aldol/Evans-Tishchenko reactions of acyclic ketones (2-butanone, 3-pentanone, propiophenone, and deoxybenzoin) with aldehydes (benzaldehyde, propionaldehyde, and isobutyraldehyde) occurred in a highly<smiles>O=C(OC(c1ccccc1)c1ccccc1)C1CCC1O</smiles><smiles>[R7]C1CCC(O)([C@H](OC(=O)c2ccccc2)c2ccccc2)C1</smiles>

69a $R^{1}, R^{2}=0$

70a $R^{1}, R^{2}=\mathrm{OCH}_{2} \mathrm{CH}_{2} \mathrm{O}$

71a $R^{1}=M e, R^{2}=H$

72a $R^{1}=t-B u, R^{2}=H$<smiles>O=C(OC(c1ccccc1)C1COCCC1O)c1ccccc1</smiles>

73a<smiles>O=C(O[C@H](c1ccccc1)C1CCc2ccccc2C1O)c1ccccc1</smiles>

$75 a$<smiles>OC(c1ccccc1)C1C2CC3CC1(O)C3C2</smiles>

67a $\mathrm{R}=\mathrm{COPh}, \mathrm{n}=1$

$67 \mathrm{c} R=\mathrm{H}, \mathrm{n}=1$

68a $R=$ COPh, $n=2$

$68 \mathrm{c} R=\mathrm{H}, \mathrm{n}=2$

$\delta 3.31(\mathrm{td}, J 10.4,6.6)$

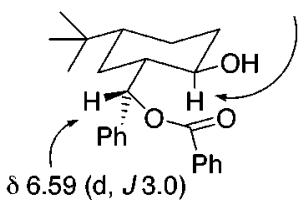

$72 a$<smiles>O=C(OC(c1ccccc1)c1ccccc1)C1CCC=CC1O</smiles>

$74 a$

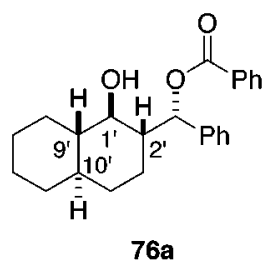

Figure 4. $\alpha, \beta$-Syn $-\alpha, \gamma$-anti products from aldol/EvansTischenko reactions of cyclic ketones.

stereoselective manner to give $\alpha, \beta$-anti- $\alpha, \gamma$-anti products $(60 a-65 a)$ according to the NMR analyses. Some of these diol monoesters (60a/60b, 61a, 61b, and 62a) were also subjected to hydrolyses to double check their structures and purity.

Aldol/Evans-Tishchenko Reactions of Cyclic Ketones. To our surprise, cyclic ketones reacted with benzaldehyde to give diol monoesters with $\alpha, \beta$-syn $-\alpha, \gamma$ anti configuration, differing from the stereochemistry in the reactions of acyclic ketones. As a direct comparison of the configuration of products, the $\beta$-carbon in compounds 66a-76a (Figure 4), obtained from the aldol/ Evans-Tishchenko reactions of cyclic ketones, is viewed as the carbon bearing a methylene substituent. For example, the reaction of cyclopentanone and benzaldehyde by the catalysis of $\mathrm{Sml}_{2}$ or $\mathrm{Sml}_{3}$ in the presence of molecular sieves afforded 67a in $85-87 \%$ yields. Hydrolysis of 67 a yiel ded an $\alpha, \beta$-syn $-\alpha, \gamma$-anti diol $67 c^{15 c}$

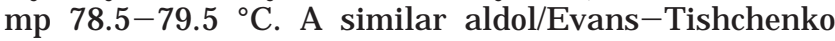
reaction of cyclohexanone with benzaldehyde afforded 68a, of which axial $\mathrm{H}-\mathbf{1}^{\prime}$ (at $\beta$-carbon) exhibited as a triplet of doublet $(J=10.0,4.2 \mathrm{~Hz})$ in the ${ }^{1} \mathrm{H} N M R$ spectrum. The assignment was confirmed by transformation of 68 a to a known $\alpha, \beta$-syn- $\alpha, \gamma$-anti diol $68 \mathrm{c},{ }^{15 c} \mathrm{mp}$ 106- $107^{\circ} \mathrm{C}$. Cyclohexane-1,4-dione underwent an aldol/ Evans-Tishchenko reaction to give the diol monoester 69a, the other carbonyl group remaining unattacked. The 
aldol/Evans-Tishchenko reaction of 2-cyclohexenone occurred at the $\alpha^{\prime}$-site (C-6), giving 74a, but not at the $\alpha$ - or $\gamma$-sites (C-2 or C-4). The aldol/Evans-Tishchenko reaction of trans-1-decalone yielded $\mathbf{7 6 a}$, of which the carbinyl proton $\left(\mathrm{H}-1^{\prime}\right)$ displayed at $\delta 3.03$ as a triplet $(\mathrm{J}$ $=9.4 \mathrm{~Hz}$ ), indicating that $\mathrm{H}-\mathrm{I}^{\prime}, \mathrm{H}-2^{\prime}$, and $\mathrm{H}-9^{\prime}$ all had axial orientation. The aldol/E vans-Tishchenko reaction products $69 a-76 a$ of cyclohexanone-derived ketones all exhibited 1,2-trans configurations as inferred from the characteristic patterns of their axial $\mathrm{C}^{-1} \mathbf{1}^{\prime}$ protons in the ${ }^{1} \mathrm{H}$ NMR spectra. An X-ray diffraction analysis of $72 a$ not only confirmed this stereochemical assignment ( $\alpha, \beta$-syn$\alpha, \gamma$-anti configuration) but also showed the equatorial disposition of the hydroxy, tert-butyl, and ( $\alpha$-benzoyloxy)benzyl groups.

Reaction Mechanism. In this study, we have demonstrated that either $\mathrm{Sml}_{2}$ or $\mathrm{Sml}_{3}$ promoted crossaldol and aldol/E vans-Tishchenko reactions in a highly stereoselective manner. $\mathrm{Sml}_{2}$ has been employed as a catalyst in aldol and other reactions. ${ }^{3 \mathrm{~d}, \mathrm{f}} \mathrm{Sml}{ }_{2}$ and $\mathrm{Sml}_{3}$ have also been used to promote intramolecular Tishchenko reactions of $\beta$-hydroxy ketones with aldehydes. ${ }^{5 c}$ The nature of the samarium catalysts in these reactions remains unclear, al though some reports suggest that only the trivalent samarium ion plays the real catalytic role. ${ }^{3 d}$

The stereochemical outcome of an aldol reaction depends on several factors, such as the steric effect of substrates, the configuration of the enolate, the type of transition state, and the reversibility of the reaction. For example, steric effects were operative in the aldol reaction of 3-methylcyclopentanone with 1,3-dichloroacetone to give predominantly the 2,4-disubstituted cyclopentanone 20 (55\%) over the 2,3-disubstituted isomer 19 (23\%).

The preference in formation of an anti-aldol $\mathbf{2 2}$ can be explained by addition of 1-chloroacetone onto the enolate of cyclopentanone (7) via a cyclic transition state D (Scheme 3). The samarium enolate of $\mathbf{7}$ can only exist as the E-form. The other possible cyclic transition state, which places the bulkier $\mathrm{CH}_{2} \mathrm{Cl}$ group in the ring, is energetically unfavorable.

Cyclic ketones can form only $\mathrm{E}$-enolates, but acyclic ketones and aldehydes may form either $\mathrm{E}$ - or Z-enolates. ${ }^{16}$ On treatment with $\mathrm{Sml}_{2}$ ( 0.3 equiv) and molecular sieves in THF, 3-pentanone was presumably to form the corresponding samarium enolates of $\mathrm{E}$ - and Z-configurations. Attempts to trap the samarium enolates with acetic anhydride or $\mathrm{Me}_{3} \mathrm{SiCl}-(\mathrm{i}-\mathrm{Pr})_{2} \mathrm{NEt}$ failed. Instead, the ring-opening products of THF,${ }^{17} 4$-iodobutyl acetate and 4-iodobutanol trimethylsilyl ether, were obtained. The samarium enolates were, however, successfully trapped by the trimethylsilyl ketene acetal prepared from methyl isobutyrate (78) to give the corresponding enol silyl ethers 79a (E-form) and 79b (Z-form) in a ratio of 7:3, according to the intensity of their vinyl protons $(\delta 4.48$ for $\mathrm{E}$-enolate and $\delta 4.29$ for Z-enolate) in the ${ }^{1} \mathrm{H}$ NMR spectrum (Scheme 4). Noteworthily, similar experiments of 5-nonanone using $\mathrm{Sml}_{2}(\mathrm{THF})_{2}, \mathrm{Sml}_{3}(\mathrm{THF})_{3}$, or $\mathrm{Sml}_{2}(\mathrm{Ot}-\mathrm{Bu})$ $(\mathrm{THF})_{3}$ in $\mathrm{CH}_{2} \mathrm{Cl}_{2}$ are reported to give preferentially the $Z$-enol silyl ether $(Z / E=3) .{ }^{18}$ The change of $E / Z$ ratio

(16) For ytterbium enolates: Fukuzawa, S.-i.; Tsuchimoto, T.; Kanai, T. Bull. Chem. Soc. J pn. 1994, 67, 2227.

(17) Examples of related reactions: (a) Oku, A.; Harada, T.; Kita, K. Tetrahedron Lett. 1982, 681. (b) Yu, Y.; Zhang, Y.; Ling, R. Synth. Commun. 1993, 23, 1973.

(18) Hydrio, J .; Van de Weghe, P.; Collin, J . Synthesis 1997, 68. may be attributable to the different nature of Lewis acids, solvent systems, and reaction substrates.

The aldol reactions of $(\mathrm{R})$-glyceral dehyde acetonide (or related cycl ohexanone ketal) with metal enolates, ${ }^{19}$ e.g., $\mathrm{Li}(\mathrm{I})$-, Sn(II)-, and Sm(III)-enolates, are believed to follow the Conforth dipolar mode ${ }^{20}$ This reaction mode accounts for the formation of (S)-carbinyl centers in aldols $\mathbf{2 6}$ and 27 and 29-32. The aldol reactions with samarium enolates often proceed with Zimmerman-Traxler chairlike transition states (Scheme 4). ${ }^{1}$ Accordingly, an E-enolate 77a should yield an anti-aldol 27, via the transition state $\mathbf{E}$, whereas a Z-enol ate $\mathbf{7 7 b}$ should yield a syn-aldol $\mathbf{8 0}$, via the transition state $\mathbf{F}$. However, the aldol reaction of 3-pentanone with ( $R$ )-glyceraldehyde acetonide actual ly results in a single product $\mathbf{2 7}$, even if both E- and Z-enolates are present at an early stage of this reaction. How can one interpret this phenomenon? We may assume that the transition state $\mathbf{F}$ is energetically less favorable than $\mathbf{E}$ due to steric effects such as the pentane-gauche repulsions of the methyl group with the dioxolane ring or the repulsion of the methyl group with the ligands attached to the samarium ion. Thus, addition of (R)-glyceral dehyde acetonide to the Z-enolate (via F) is conceivably slow. Instead, the Z-enolate $\mathbf{7 7 b}$ may revert to the $\mathrm{E}$-enolate $\mathbf{7 7 a}$, which reacts rapidly with (R)-glyceral dehyde acetonide via the energetically favorable transition state $\mathbf{E}$ to give the anti-aldol $\mathbf{2 7}$. In this case, the anti-aldol $\mathbf{2 7}$ is also likely more stable than the corresponding syn isomer.

Intramolecular Tishchenko reactions are believed to proceed with bicyclic transition states to give $\alpha, \gamma$-anti diol monoesters in a stereospecific manner. Evans and Hoveyda ${ }^{5 c}$ have shown that the Tishchenko reactions of $\beta$-hydroxy ketones using $\mathrm{Sml}_{2}$ as promoters are stereospecific processes with $\alpha, \beta$-configuration unchanged. For example, the reaction of $\alpha, \beta$-syn aldol $\mathbf{8 6}$ was treated with isobutyraldehyde (4-8 equiv) at $-10{ }^{\circ} \mathrm{C}$ for $0.5-$ $0.75 \mathrm{~h}$ in the presence of $\mathrm{Sml}_{2}$ (15 mol \%) to give an $\alpha, \beta$ syn- $\alpha, \gamma$-anti diol monoester 90 (entry 2, Table 6). On the other hand, Mahrwal d and Costisella ${ }^{8 \mathrm{c}}$ have demonstrated that treatment of an $\alpha, \beta$-syn aldol 82 with benzal dehyde in the presence of $\mathrm{BuTi}(\mathrm{Oi}-\mathrm{Pr})_{4} \mathrm{Li}$ at room temperature for $24 \mathrm{~h}$ led to the $\alpha, \beta$-anti- $\alpha, \gamma$-anti diol monoester $\mathbf{6 1} \mathbf{a}$ and its transesterification isomer $\mathbf{6 1 \mathbf { b }}$, but no $\alpha, \beta$-syn- $\alpha, \gamma$-anti product 87 (entry 1, Table 6; Scheme $5)$. This stereochemical outcome is different from that observed by Evans and Hoveyda. It seems that syn-aldol $\mathbf{8 2}$ isomerizes to anti-aldol $\mathbf{8 1}$ prior to the Tischenko reaction, though no evidence is provided.

To gain insight into this problem, we prepared a mixture of aldols 85 and 86 (anti/syn = 64:36) from isobutyraldehyde and the lithium enolate of 3-pentanone. The mixture of 85/86 in THF solution was then treated with isobutyraldehyde (2.5 equiv) in the presence of $\mathrm{Sml}_{2}$ (0.3 equiv) and molecular sieves. After stirring at $0{ }^{\circ} \mathrm{C}$ for $1 \mathrm{~h}$, compounds 63a and $\mathbf{9 0}$ were isolated in a ratio of 76:24 (entry 3, Table 6). After additional stirring at $22{ }^{\circ} \mathrm{C}$ for $1 \mathrm{~h}$, the content of $\mathbf{9 0}$ further decreased $(\mathbf{6 3 a} /$ $90=82: 18$ ). This result may account for a partial

(19) F or reviews of the reactions of (R)-glyceraldehyde acetonide: (a) J urczak, J .; Pikul, S.; Bauer, T. Tetrahedron 1986, 42, 447. (b) Heathcock, C. H.; Young, S. D.; Hagen, J . P.; Pirrung, M. C.; White, C. T.; VanDerveer, D. J . Org. Chem. 1980, 45, 3846. (c) Murakami, M.; Kawano, T.; Ito, Y. J . Am. Chem. Soc. 1990, 112, 2437.

(20) Eliel, E. L. In Asymmetric Synthesis; Morrison, J . D., Ed.; Academic Press: New York, 1984; Vol. 2, pp 125-155. 
Table 6

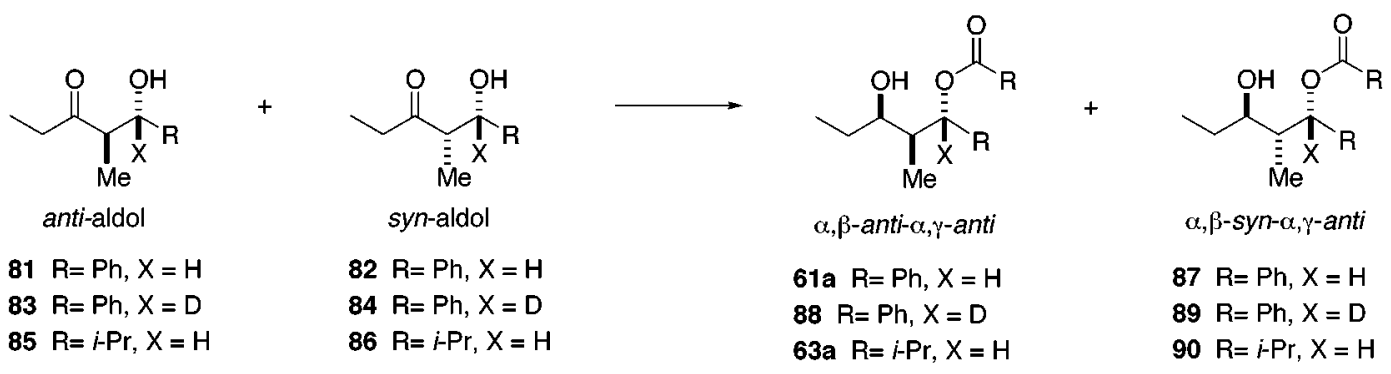

\begin{tabular}{clll}
\hline entry no. & \multicolumn{1}{c}{ reactants } & \multicolumn{1}{c}{ reaction conditions } & \multicolumn{1}{c}{ products } \\
\hline $1^{\mathrm{a}}$ & $\mathbf{8 2}+\mathrm{PhCHO}$ & $\mathrm{BuTi}(\mathrm{Oi}-\mathrm{Pr})_{4} \mathrm{Li}, \mathrm{rt}, \mathbf{2 4 \mathrm { h }}$ & $\mathbf{6 1 a}+\mathbf{6 1 b}$ \\
$2^{\mathrm{b}}$ & $\mathbf{8 6}+\mathrm{i}-\mathrm{PrCHO}(4-8$ equiv) & $\mathrm{Sml}_{2}(15 \mathrm{~mol} \%),-10{ }^{\circ} \mathrm{C}, 0.5-0.75 \mathrm{~h}$ & $\mathbf{9 0}$ \\
3 & $\mathbf{8 5 / 8 6}(64: 36)+\mathrm{i}-\mathrm{PrCHO}(2.5$ equiv) & $\mathrm{Sml}_{2}(30 \mathrm{~mol} \%), \mathrm{MS}, 0{ }^{\circ} \mathrm{C}, 1 \mathrm{~h}$ & $\mathbf{6 3 a} / \mathbf{9 0}(76: 24)$ \\
4 & $\mathbf{8 5 / 8 6}(64: 36)+\mathrm{i}-\mathrm{PrCHO}(2.5$ equiv) & $\mathrm{Sml}_{2}(30 \mathrm{~mol} \%), \mathrm{MS}, 0{ }^{\circ} \mathrm{C}(1 \mathrm{~h}), 22{ }^{\circ} \mathrm{C}(1 \mathrm{~h})$ & $\mathbf{6 3 a} / \mathbf{9 0}(82: 18)$ \\
5 & $\mathbf{8 1 / 8 2}(50: 50)+\mathrm{PhCHO}(2.5$ equiv) & $\mathrm{Sml}_{2}(30 \mathrm{~mol} \%), \mathrm{MS}, 0{ }^{\circ} \mathrm{C}, 0.5 \mathrm{~h}$ & $\mathbf{6 1 a}$ \\
6 & $\mathbf{8 3 / 8 4}(50: 50)+\mathrm{PhCHO}(2.5$ equiv) & $\mathrm{Sml}_{2}(30 \mathrm{~mol} \%), \mathrm{MS}, 0{ }^{\circ} \mathrm{C}, 0.5 \mathrm{~h}$ & $\mathbf{6 1 a}(>80 \%)$
\end{tabular}

a The data are adapted from ref 8 e. Compound $\mathbf{6 1 b}$ is the transesterification isomer of $\mathbf{6 l a}$. ${ }^{b}$ The data are adapted from ref $5 c$.

isomerization of syn-aldol $\mathbf{8 6}$ to anti-aldol $\mathbf{8 5}$ prior to the Tishchenko reaction. Furthermore, we prepared a 1:1 mixture of $\mathbf{8 1}$ and $\mathbf{8 2}$ and treated it with benzaldehyde (2.5 equiv) in the presence of $\mathrm{Sml}_{2}$ ( 0.3 equiv) and molecular sieves at $0{ }^{\circ} \mathrm{C}$ for $0.5 \mathrm{~h}$. Only the $\alpha, \beta$-anti$\beta, \gamma$-syn diol monoester 61a was obtained, indicating a very rapid isomerization of syn-aldol $\mathbf{8 2}$ to anti-aldol $\mathbf{8 1}$. These results were in agreement with the higher reversibility of benzaldehyde than that of isobutyraldehyde in retro-aldol reactions.

I somerization between anti and syn aldols (or corresponding metal aldolates) may proceed with enolizationprotonation (via aldol enolate $\mathbf{H}$ ) or dissociationrecombination (via enolates $\mathbf{G}$ ) pathways (Scheme 5). We thus designed the following experiment to distinguish these two possible pathways. We prepared a 1:1 mixture of deuterated compounds $\mathbf{8 3}$ and $\mathbf{8 4}$ from PhCDO and the lithium enolate of 3-pentanone. The THF solution of this deuterium-containing mixture was then treated with PhCHO (2.5 equiv) in the presence of $\mathrm{Sml}_{2}$ (0.3 equiv) and molecular sieves at $0^{\circ} \mathrm{C}$ for $0.5 \mathrm{~h}$ (entry 6 , Table 6). After which, compound 61a (containing no deuterium) was obtained as the major product according to the ${ }^{1} \mathrm{H}$ NMR analysis. Thus, dissociation of $\mathbf{8 3 / 8 4}$ occurred to give the enolates $\mathbf{G}$, and recombination of $\mathbf{G}$ with $\mathrm{PhCHO}$ led to aldols $\mathbf{8 1 / 8 2}$. This dissociation-recombination process proceeded until an equilibrium was reached, presumably in favor of the anti aldolate.

From the previous reports ${ }^{5 c, 8 c}$ and our current studies, a picture of the tandem aldol-Tishchenko reaction can be drawn: (i) A Lewis acid catalyst (such as titanium complex, $\mathrm{Sml}_{2}, \mathrm{Sml}_{2}-\mathrm{MS}$, or $\mathrm{Sml}_{3}-\mathrm{MS}$ ) can promote interconversion between anti and syn aldols under appropriate reaction conditions. (ii) Such interconversion follows a dissociation-recombination pathway. (iii) The rate of isomerization of aldols depends on several factors. The aldols derived from benzaldehyde (e.g., 81/82) reached equilibrium faster than the isobutyral dehyde counterpart (e.g., 85/86). (iv) The isomerization of aldols and the subsequent Tishchenko reactions are facilitated at a higher temperature (compared entries 2-4 in Table 6). (v) Aldol reaction is reversible, whereas Tishchenko reaction is irreversible. The difference of rates in these two reactions is an important factor to determine the stereochemical outcome of the final diol monoester

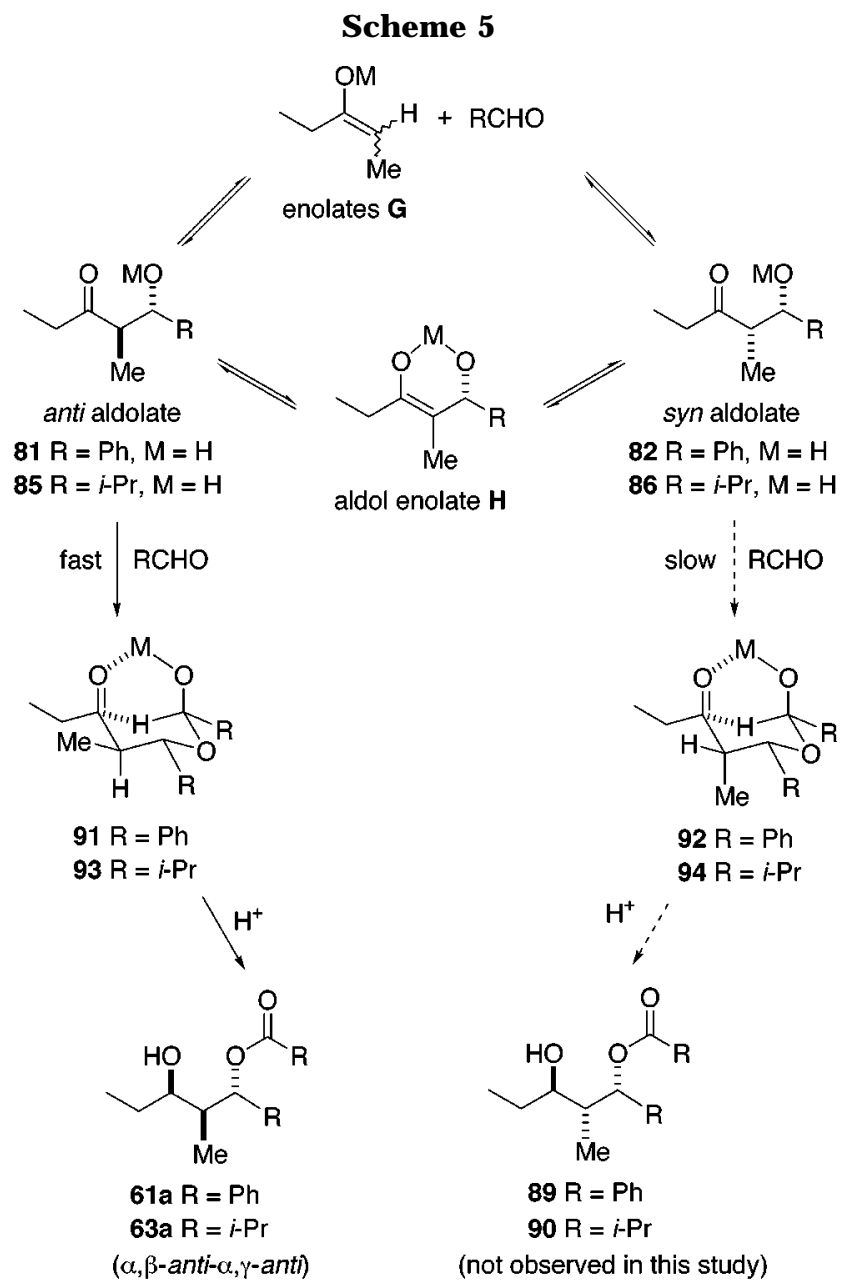

products. (vi) Tishchenko reactions are stereospecific processes. An $\alpha, \beta$-anti aldol (e.g., 81 or 85) proceeds with a bicyclic transition state (e.g., 91 or 93) to give an $\alpha, \beta$ anti- $\alpha, \gamma$-anti diol monoester (e.g., 61a or 63a). An $\alpha, \beta$-syn aldol (e.g., 82 or $\mathbf{8 6}$ ) can undergo a similar Tishchenko reaction with a slower rate through the transition state $\mathbf{9 2}$ or 94, the methyl group of which occupies an energetically unfavorable axial position, to give an $\alpha, \beta$-syn- $\alpha, \gamma$-anti diol monoester (e.g., 89 or 90). In such cases, a fast isomerization from syn-aldol to anti- 
aldol may surpass the rate of Tishchenko reaction. Thus, a syn-aldol may isomerize to an anti-aldol and undergoes a subsequent Tishchenko reaction via the more favorable transition state (e.g., 91 or $\mathbf{9 3}$ ) to afford the observed $\alpha, \beta$ anti- $\alpha, \gamma$-anti products. (vii) Transesterification of diol monoesters can occur, but this process can also be avoided by lowering the reaction temperature (e.g. transesterification of $\mathbf{6 1 a}$ to $\mathbf{6 1} \mathbf{b}$ occurred at room temperature but was inhibited at $0^{\circ} \mathrm{C}$ ).

At first glance, one is perplexed that aldol/EvansTishchenko reactions of cyclic and acyclic ketones show a dichotomous stereochemical course. The exclusive formation of $\alpha, \beta$-syn- $\alpha, \gamma$-anti diol monoesters must result from the Tishchenko reactions of $\alpha, \beta$-syn aldols. Addition of the E-enolates of cyclic ketones to benzaldehyde hardly gives only syn-aldols; ${ }^{21}$ however, anti-aldols (e.g., 95) can isomerize to syn-aldols (e.g., 96) via a dissociation-recombination pathway (Scheme 6). If one assumes that syn-aldol $\mathbf{9 6}$ undergoes an intramolecular Tishchenko reaction faster than anti-aldol 95, the preferable formation of $\alpha, \beta$-syn- $\alpha, \gamma$-anti diol monoester 68a can be realized. We speculate that the transition state 98, having $\mathrm{H}^{-}$attack the cyclohexanone moi ety from the axial direction, is superior to an equatorial $\mathrm{H}^{-}$attack in the transition state 97. Many previous studies support that axial $\mathrm{H}^{-}$delivery to cyclohexanones is a kinetically favored process. ${ }^{22}$ This selective axial addition is very likely applicable to the Tishchenko reactions exemplified in this paper. Under such circumstances, a product development control also favors the formation of the more stable equatorial alcohol (e.g., 68a). The aldolTishchenko reactions of substituted cyclohexanones, 2-cyclohexenone, tetrahydropyranone, $\alpha$-tetralone, and trans-decalone, with benzaldehyde all follow a similar mechanism to give $\alpha, \beta$-syn $-\alpha, \gamma$-anti products $69 \mathbf{a}-\mathbf{7 6}$ a Formation of 67a ( $\alpha, \beta$-syn- $\alpha, \gamma$-anti configuration) in the aldol/Evans-Tishchenko reaction of cyclopentanone is also consistent with a preferable pseudoaxial hydride shift. In the reaction of cyclobutanone, the cis-devel oping [4.2.0]bicyclic transition state $\mathbf{1 0 0}$ is considered more favorable than the trans-devel oping transition state 101; the reaction thus leads to the $\alpha, \beta$-syn- $\alpha, \gamma$-anti product 66a. Interestingly, Curran and Wolin ${ }^{8 b}$ have proposed a similar transition state for an aldol-Tishchenko reaction in a cis-bicyclo[3.3.0]octan-3-one system, though the configuration of the diol monoester product is not rigorously determined.

Conclusion. Although the nature of $\mathrm{Sml}_{2}-\mathrm{MS}$ or $\mathrm{Sml}_{3}-\mathrm{MS}$ is not fully understood, they do function differently, at least to a certain degree, from using $\mathrm{Sml}_{2}$ or $\mathrm{Sml}_{3}$ alone. This study shows that $\mathrm{Sml}_{2}-\mathrm{MS}$ can function as an effective Lewis acid to promote cross-aldol and aldol/Evans-Tishchenko reactions. The reactions occur in highly stereoselective manners under mild conditions $\left(0-25^{\circ} \mathrm{C}\right)$. Highly enolizable ketones, such as

(21) For related studies: (a) Majewski, M.; Gleave, D. M. Tetrahe dron Lett. 1989, 30, 5681. (b) J uaristi, E.; Beck, A. K.; Hansen, J .; Matt, T.; Mukhopadhyay, T.; Simson, M.; Seebach, D. Synthesis 1993, 1271 (c) Ranu, B. C.; Chakreborty, R. Tetrahedron 1993, 49, 5333. (d) Kobayashi, S.; Hachiya, I. J . Org. Chem. 1994, 59, 3590. Uncatalyzed aldol reaction of (trichlorosilyl)oxycycl ohexene with benzal dehyde may undergo a boatlike transition state to give predominantly a syn-aldol product. See: (e) Denmark, S. E.; Wong, K.-T.; Stavenger, R. A. J . Am Chem. Soc. 1997, 119, 2333.

(22) (a) Greeves, N. In Comprehensive Organic Synthesis; Trost, B M., Fleming, I., Eds.; Pergamon Press: Oxford, 1991; Vol. 8, Chapter 1.1, pp 5-7. (b) Ashby, E. C.; Laemmle, J. T. Chem. Rev. 1975, 75, 521.

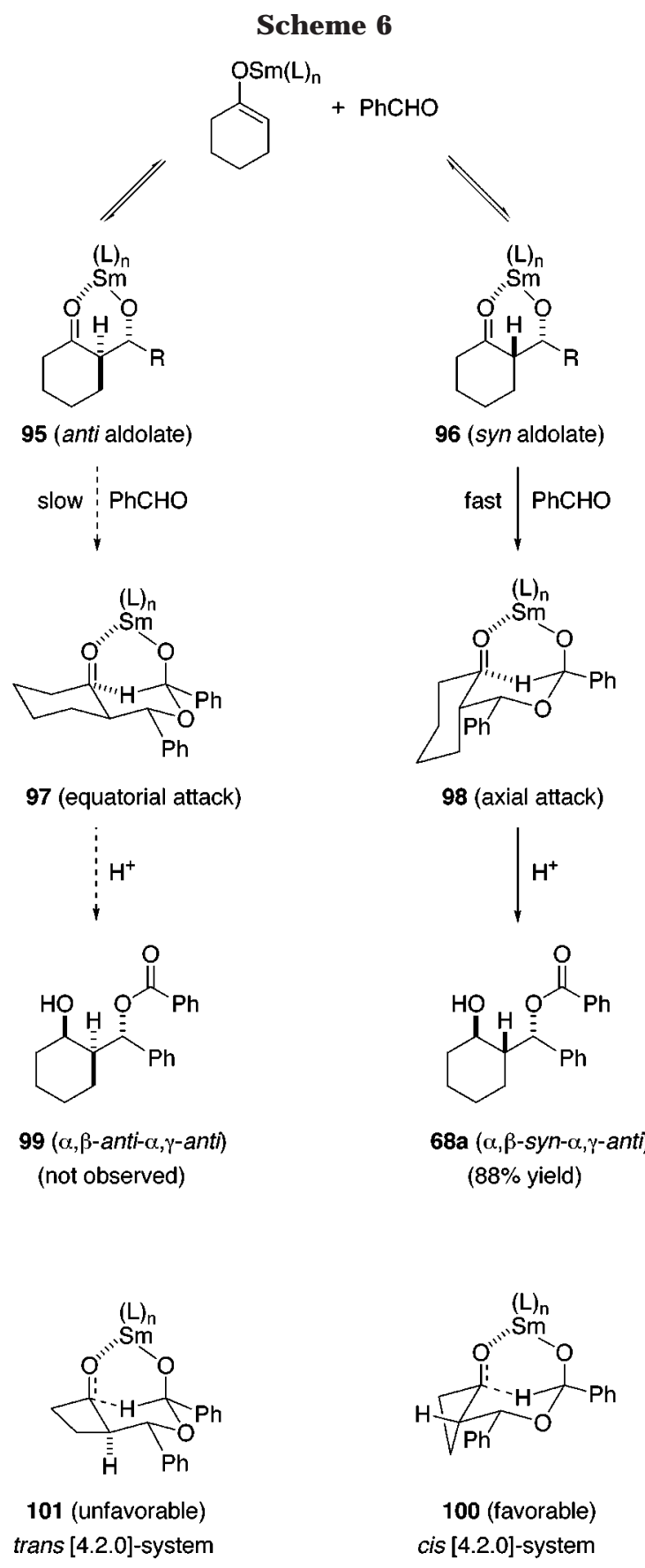

1,3-dichloroacetone, are successfully used as the acceptor substrates in the cross-aldol reactions. The dichotomous stereochemistry in aldol/Evans-Tishchenko reactions of cyclic and acyclic ketones is an unprecedented finding. When (R)-glyceraldehyde acetonide is employed as the acceptor substrate, the cross-aldol and aldol/EvansTishchenko reactions occur in a stereoselective fashion to afford enantiomerically pure compounds. Application of this method to the synthesis of complex natural products is promising.

\section{Experimental Section}

Melting points are uncorrected. Optical rotations were measured on a digital polarimeter with a cuvette of $1 \mathrm{~cm}$ length. ${ }^{1} \mathrm{H}$ NMR spectra were recorded at 200,300 , or 500 $\mathrm{MHz} ;{ }^{13} \mathrm{C}$ NMR spectra were recorded at 50,75 , or $125 \mathrm{MHz}$. $\mathrm{CHCl}_{3}(\delta=7.24 \mathrm{ppm})$ was used as an internal standard in ${ }^{1} \mathrm{H}$ 
NMR spectra. Mass spectra were recorded at an ionizing vol tage of 70 or $20 \mathrm{eV}$. Merck silica gel 60F sheets were used for analytical thin-layer chromatography. Column chromatography was performed on silica gel (70-230 mesh) or alumina (neutral); gradients of EtOAc and n-hexane were used as eluents. HPLC was performed on a Hibar Lichrosorb Si 60 (7 $\mu \mathrm{m})$ column $(25 \mathrm{~cm} \times 1 \mathrm{~cm}$ i.d. $)$ with the indicated eluent at a $5 \mathrm{~mL} / \mathrm{min}$ flow rate. THF was distilled from sodium benzophe none ketyl under $\mathrm{N}_{2}$.

General Procedure for Aldol Reactions Promoted by Samarium Diiodide and Molecular Sieves (Tables 1-3). In an oven-dried round-bottomed flask $(50 \mathrm{~mL})$ was placed samarium metal (1.13 g, $7.51 \mathrm{mmol}), 1,2$-diiodoethane (2.10 $\mathrm{g}, 7.45 \mathrm{mmol}$ ), and molecular sieves (4 $\AA, 200 \mathrm{mg})$. The air was evacuated by pump. The flask was inflated with argon and capped with a septum. Anhydrous THF (12 mL) was added via syringe. The mixture was vigorously stirred at room temperature $\left(20-25^{\circ} \mathrm{C}\right)$ for $15-20 \mathrm{~min}$ to give a deep blue suspension (0.36 M).

Method A. A donor substrate $(3.72 \mathrm{mmol})$ in THF $(2 \mathrm{~mL})$ was added dropwise to the deep blue suspension, and the mixture was stirred at room temperature for 5-20 min, after which, an acceptor substrate $(4.09 \mathrm{mmol})$ in THF $(2 \mathrm{~mL})$ was added dropwise. The mixture was stirred for an appropriate period, the septum was removed, and the mixture was stirred for additional $10 \mathrm{~min}$ in the air to give a yellow suspension. The mixture was filtered and rinsed with $\mathrm{CH}_{2} \mathrm{Cl}_{2}(2 \times 25 \mathrm{~mL})$. The filtrate was concentrated by rotary evaporation. The residue was passed through a short column packed with alumina (neutral, $20-25 \mathrm{~g}$ ) and eluted with gradients of EtOAc and hexane to give the desired aldol products.

Method B. A mixture of donor $(3.72 \mathrm{mmol})$ and acceptor (4.09 $\mathrm{mmol})$ substrates in THF $(4 \mathrm{~mL})$ was added to the deep blue suspension. In certain cases (Table 3$)$, t-BuOH $(0.71 \mathrm{~mL}$, $7.45 \mathrm{mmol}$ ) was added. The workup procedure was similar to that described in method $A$.

General Procedure for Tandem Aldol/EvansTishchenko Reactions Promoted by Samarium Ions (Tables 4 and 5). (i) The dark blue $\mathrm{Sml}_{2}(0.1 \mathrm{M})-\mathrm{THF}(3 \mathrm{~mL})$ suspension was prepared by treatment of Sm (45.1 mg, 0.3 $\mathrm{mmol}$ ) with diiodoethane $(84.5 \mathrm{mg}, 0.3 \mathrm{mmol})$ in the presence of molecular sieves ( $4 \AA, 100 \mathrm{mg})$ by the above-mentioned procedure. (ii) The yellow $\mathrm{Sml}_{3}(0.06 \mathrm{M})$-THF $(5 \mathrm{~mL})$ suspension was prepared by treatment of $\mathrm{Sm}(45.1 \mathrm{mg}, 0.3 \mathrm{mmol})$ with $\mathrm{I}_{2}$ (114.2 $\mathrm{mg}, 0.45 \mathrm{mmol}$ ) in the presence of molecular sieves (4 A, $100 \mathrm{mg})$. (iii) A donor substrate $(1.0 \mathrm{mmol})$ in THF $(0.5 \mathrm{~mL})$ was added at $0{ }^{\circ} \mathrm{C}$ to the $\mathrm{Sml}_{2}$ or $\mathrm{Sml}_{3}$ suspension prepared from steps (i) or (ii). The mixture was stirred for 40 min, and an acceptor substrate $(2.5 \mathrm{mmol})$ in THF $(1.5 \mathrm{~mL})$ was added dropwise. The mixture was stirred for an appropriate period at $0{ }^{\circ} \mathrm{C}$ and then warmed to room temperature. The mixture was filtered and rinsed with $\mathrm{CH}_{2} \mathrm{Cl}_{2}$. The filtrate was concentrated by rotary evaporation. The residue was passed through a short column packed with alumina (neutral) and eluted with gradients of EtOAc and hexane to give the desired products of diol monoesters.

2-(1-Chloro-2-hydroxyprop-2-yl)cyclopentanone (22). Treatment of cyclopentanone (301 mg, $3.58 \mathrm{mmol})$ with 1chloroacetone (364 mg, $3.94 \mathrm{mmol}$ ) according to the general procedure (method A) gave the title compound (474 mg, 75\%) having the ( 1 'S*,2R*)-configuration: oil; TLC (EtOAc/hexane $(20: 80)) R_{f}=0.82 ;$ IR (neat) $3342,1739 \mathrm{~cm}^{-1} ;{ }^{1} \mathrm{H} \mathrm{NMR}\left(\mathrm{CDCl}_{3}\right)$ $\delta 1.19(3 \mathrm{H}, \mathrm{s}), 1.58-1.80(2 \mathrm{H}, \mathrm{m}), 2.03-2.47(4 \mathrm{H}, \mathrm{m}), 2.58$ $(1 \mathrm{H}, \mathrm{dd}, \mathrm{J}=8.2 \mathrm{~Hz}, 8.7 \mathrm{~Hz}), 3.48,3.58(2 \mathrm{H}, \mathrm{AB}$ quartet, $\mathrm{J}=$ $11.5 \mathrm{~Hz}), 3.97(1 \mathrm{H}, \mathrm{s}, \mathrm{OH}) ;{ }^{13} \mathrm{C} \mathrm{NMR}\left(\mathrm{CDCl}_{3}\right) \delta 20.1$ (q), 22.3 (t), $26.1(\mathrm{t}), 39.4(\mathrm{t}), 52.0(\mathrm{t}), 54.3(\mathrm{~d}), 73.4(\mathrm{~s}), 222.6(\mathrm{~s}) ; \mathrm{MS}$ $\mathrm{m} / \mathrm{z}$ (rel intensity) $140\left(32, \mathrm{M}^{+}-\mathrm{HCl}\right), 83(100)$. HRMS Cal cd for $\mathrm{C}_{8} \mathrm{H}_{12} \mathrm{O}_{2}\left(\mathrm{M}^{+}-\mathrm{HCl}\right)$ : 140.0837 . Found: 140.0836 .
2-[1-Hydroxy-2,3-(isopropylidenedioxy)prop-1-yl]cyclohexanone (30). Treatment of cyclohexanone (387 mg, $3.94 \mathrm{mmol}$ ) with (R)-glyceral dehdye acetonide (465 mg, 3.58 $\mathrm{mmol}$ ) in the presence of t-BuOH $(530 \mathrm{mg}, 7.16 \mathrm{mmol})$ according to the general procedure (method $\mathrm{B}$ ) gave the title compound (557 $\mathrm{mg}, 62 \%$ ) having the ( $\left.1^{\prime} \mathrm{S}, 2 \mathrm{R}, 2^{\prime} \mathrm{R}\right)$-configuration. The reaction using method $\mathrm{A}$ gave a $50 \%$ yiel d of 30: oil: TLC (EtOAc/hexane (50:50)) $\mathrm{R}_{\mathrm{f}}=0.5 ;[\alpha]^{26}{ }_{\mathrm{D}}-66\left(\mathrm{CHCl}_{3}, \mathrm{C}=\right.$ 1.0); IR (neat) 3432, $1702 \mathrm{~cm}^{-1}$; ${ }^{1} \mathrm{H}$ NMR $\left(\mathrm{CDCl}_{3}\right) \delta 1.34(3 \mathrm{H}$, s), $1.39(3 \mathrm{H}, \mathrm{s}), 1.18-2.44(9 \mathrm{H}, \mathrm{m}), 2.62-2.80(1 \mathrm{H}, \mathrm{m}), 3.28-$ $3.42(1 \mathrm{H}, \mathrm{m}), 3.90-4.22(3 \mathrm{H}, \mathrm{m}) ;{ }^{13} \mathrm{C} \mathrm{NMR}\left(\mathrm{CDCl}_{3}\right) \delta 25.3(2$ C), $26.8(\mathrm{q}), 28.2(\mathrm{t}), 32.3(\mathrm{t}), 43.2(\mathrm{t}), 51.7(\mathrm{~d}), 67.7(\mathrm{t}), 70.4$ (d), 75.0 (d), 109.3 (s), 216.1 (s); MS m/z (rel intensity) 228 (3, $\mathrm{M}^{+}$), 101 (100); HRMS Calcd for $\mathrm{C}_{12} \mathrm{H}_{20} \mathrm{O}_{4}\left(\mathrm{M}^{+}\right)$: 228.1361 . Found: 228.1359.

5-Hydroxy-4-methylhept-3-yl Propanoate (62a) and 4-Methylheptane-3,5-diol (62c). The Sml 2-promoted aldolTishchenko reaction of 3-pentanone $(86 \mathrm{mg}, 1.0 \mathrm{mmol})$ and propionaldehyde ( $145 \mathrm{mg}, 2.5 \mathrm{mmol}$ ) at $0{ }^{\circ} \mathrm{C}$, according to the general procedure, gave 62a (149 mg, 79\%; 3R*,4S*,5R*_ configuration). Saponification of $\mathbf{6 2 a}$ in saturated aqueous $\mathrm{NaOH}(5 \mathrm{~mL})$ and $\mathrm{MeOH}(1 \mathrm{~mL})$ for $2 \mathrm{~h}$ gave the corresponding diol 62c (3R*,5R*-configuration). 62a: oil; TLC (EtOAc/hexane (5:95)) $\mathrm{R}_{\mathrm{f}}=0.3$; IR (neat) 3438, $1725 \mathrm{~cm}^{-1} ;{ }^{1} \mathrm{H} \mathrm{NMR}\left(\mathrm{CDCl}_{3}\right.$, $200 \mathrm{MHz}) \delta 0.79-0.97(9 \mathrm{H}, \mathrm{m}), 1.14-1.71(8 \mathrm{H}, \mathrm{m}), 2.37(2$ $\mathrm{H}, \mathrm{q}, \mathrm{J}=7.5 \mathrm{~Hz}), 3.04(1 \mathrm{H}, \mathrm{m}), 3.36(1 \mathrm{H}, \mathrm{d}, \mathrm{J}=4.1 \mathrm{~Hz}, \mathrm{OH})$, $5.14(1 \mathrm{H}, \mathrm{m}) ;{ }^{13} \mathrm{C} \mathrm{NMR}\left(\mathrm{CDCl}_{3}, 75 \mathrm{MHz}\right) \delta 9.2,9.5,9.8,10.2$, 24.7, 27.7 (2 C), 38.8, 64.2, 74.8, 175.6; MS m/z (rel intensity) $201\left(1, \mathrm{M}^{+}-1\right)$, 57 (100). HRMS Calcd for $\mathrm{C}_{11} \mathrm{H}_{21} \mathrm{O}_{3}\left(\mathrm{M}^{+}-1\right)$ : 201.1491. Found: 201.1502. 62c: oil; ${ }^{1} \mathrm{H} N \mathrm{NMR}\left(\mathrm{CDCl}_{3}, 200\right.$ $\mathrm{MHz}) \delta 0.86(3 \mathrm{H}, \mathrm{d}, \mathrm{J}=7.4 \mathrm{~Hz}), 0.92(6 \mathrm{H}, \mathrm{t}, \mathrm{J}=7.4 \mathrm{~Hz})$, $1.30-1.88(4 \mathrm{H}, \mathrm{m}), 1.98-2.06(1 \mathrm{H}, \mathrm{m}), 2.81(2 \mathrm{H}, \mathrm{br} \mathrm{s}), 3.60-$ $3.70(2 \mathrm{H}, \mathrm{m}) ;{ }^{13} \mathrm{C} \mathrm{NMR}\left(\mathrm{CDCl}_{3}, 75 \mathrm{MHz}\right) \delta 9.9,10.5(2 \mathrm{C})$, 26.8 (2 C), 38.6, 67.0, 75.9. Anal. Calcd for $\mathrm{C}_{8} \mathrm{H}_{18} \mathrm{O}_{2}: \mathrm{C}, 65.7$; $\mathrm{H}$, 12.4. Found: $\mathrm{C}, 65.5 ; \mathrm{H}, 12.6$.

$\alpha$-(2-Hydroxycyclohex-1-yl)benzyl Benzoate (68a) and 2-( $\alpha$-Hydroxybenzyl)cyclohexanol (68c). The Sml 2 -promoted aldol-Tishchenko reaction of cyclohexanone $(98 \mathrm{mg}, 1.0$ $\mathrm{mmol}$ ) and benzaldehyde ( $265 \mathrm{mg}, 2.5 \mathrm{mmol}$ ) at $0{ }^{\circ} \mathrm{C}$, according to the general procedure, gave 68 a (273 $\mathrm{mg}, 88 \%$ ) having the $\left(1 S^{*}, 1^{\prime} R^{*}, 2^{\prime} \mathrm{R}^{*}\right)$-configuration. The reaction promoted by $\mathrm{Sml}_{3}$ gave $68 \mathbf{a}$ in $89 \%$ yield. Saponification of $\mathbf{6 8 a}$ in saturated aqueous $\mathrm{NaOH}(5 \mathrm{~mL})$ and $\mathrm{MeOH}(1 \mathrm{~mL})$ for $2 \mathrm{~h}$ gave the corresponding diol 68c (1R*, $\left.1^{\prime} R^{*}, 2^{\prime} R^{*}\right) .{ }^{15 c}$ 68a: oil; TLC (EtOAc/hexane (10:90)) $\mathrm{R}_{\mathrm{f}}=0.6$; IR (neat) $3438,1720 \mathrm{~cm}^{-1}$; ${ }^{1} \mathrm{H} \mathrm{NMR}\left(\mathrm{CDCl}_{3}, 200 \mathrm{MHz}\right) \delta 0.99-1.26(3 \mathrm{H}, \mathrm{m}), 1.31-1.42$ (5 H, m), 1.99-2.93 (1 H, m), $3.33(1 \mathrm{H}, \mathrm{br} \mathrm{s}), 3.38(1 \mathrm{H}, \mathrm{td}, \mathrm{J}$ $=10.0,4.2 \mathrm{~Hz}), 6.62(1 \mathrm{H}, \mathrm{d}, \mathrm{J}=2.1 \mathrm{~Hz}), 7.25-7.61(8 \mathrm{H}, \mathrm{m})$, 8.12-8.18 $(2 \mathrm{H}, \mathrm{m}) ;{ }^{13} \mathrm{C} N M R\left(\mathrm{CDCl}_{3}, 50 \mathrm{MHz}\right) \delta 23.3,24.7$, 25.3, 34.5, 51.9, 70.1, 74.2, 125.7 (2 C), 127.1, 128.1 (2 C), 128.2, 128.5 (2 C), 129.7, 129.8, 133.3, 139.3, 166.5; MS m/z (rel intensity) $310\left(10, \mathrm{M}^{+}\right), 105$ (100). HRMS Calcd for $\mathrm{C}_{20} \mathrm{H}_{22} \mathrm{O}_{3}$ $\left(\mathrm{M}^{+}\right)$: 310.1568. Found: 310.1566. 68c: solid (recrystallized from $\mathrm{Et}_{2} \mathrm{O}$-hexane), $\mathrm{mp} 106-107^{\circ} \mathrm{C}$, lit. ${ }^{15 \mathrm{c}} 106-107.5^{\circ} \mathrm{C} ;{ }^{13} \mathrm{C}$ $\mathrm{NMR}\left(\mathrm{CDCl}_{3}, 75 \mathrm{MHz}\right) \delta 24.3,25.3,26.1,35.7,50.0,71.4,76.9$, 126.7 (2 C), 127.2, 127.9 (2 C), 141.9.

Acknowledgment. We thank the National Science Council of the Republic of China for financial support (NSC 87-2113-M-002-042).

Supporting Information Available: Additional experimental procedures, spectral data, and NMR spectra of new compounds, as well as the crystal data, bond distances, bond angles, and an ORTEP drawing of compound 72a. This material is available free of charge via the Internet at $h t t p: / /$ pubs.acs.org.

J O981675B 